\title{
Financial Development, Financial Structure, and Domestic Investment: International Evidence
}

\author{
Léonce Ndikumana \\ Department of Economics \\ University of Massachusetts \\ Thompson Hall, Box 37510 \\ Amherst, MA 01003 \\ Fax: (413) 545-2921 \\ Email: ndiku@econs.umass.edu
}

\begin{abstract}
Does it matter for domestic investment whether a country's financial system is bank based or stock-market based? This paper posits that financial intermediation affects domestic investment notably by alleviating financing constraints, allowing firms to increase investment in response to increased demand for output. The key result is that the structure of the financial system has no independent effect on investment, in the sense that it does not enhance the response of investment to changes in output, while financial development makes investment more responsive to output growth. Consequently, rather than promoting a particular type of financial structure, countries should implement policies that reduce transactions costs in financial intermediation and enforce creditor and investor rights. This will facilitate the development of banks and stock markets, which will stimulate domestic investment.
\end{abstract}

Key words: domestic investment; financial development; financial structure; bank-based systems; stock-market-based systems.

JEL classification: E22; E44

This draft: January 2003 


\title{
Financial Development, Financial Structure, and Domestic Investment: International Evidence
}

\begin{abstract}
Does it matter for domestic investment whether a country's financial system is bank based or stock-market based? This paper posits that financial intermediation affects domestic investment notably by alleviating financing constraints, allowing firms to increase investment in response to increased demand for output. The key result is that the structure of the financial system has no independent effect on investment, in the sense that it does not enhance the response of investment to changes in output, while financial development makes investment more responsive to output growth. Consequently, rather than promoting a particular type of financial structure, countries should implement policies that reduce transactions costs in financial intermediation and enforce creditor and investor rights. This will facilitate the development of banks and stock markets, which will stimulate domestic investment.
\end{abstract}

Key words: domestic investment; financial development; financial structure; bank-based systems; stock-market-based systems.

JEL classification: E22; E44 


\section{Introduction}

For over a century, economists have debated the comparative merits of bankbased systems and stock-market-based systems in mobilizing resources and enhancing economic growth (see Levine 2001 for a review of this debate). ${ }_{\text {This paper examines }}$ whether bank-based or stock-market-based financial systems are better at promoting domestic investment. To investigate this empirical question, the paper posits that financial intermediation affects investment notably by alleviating financing constraints, and that better functioning financial systems allow firms to invest more in response to increased demand for output. It follows that at the aggregate level, developed financial systems are associated with a stronger response of domestic investment to an increase in per capita GDP. This analysis draws from the accelerator theory, which predicts a positive relationship between investment and changes in output.2

The econometric analysis in this paper is based on a sample of 99 countries including developed and developing countries for the period 1965-1997. The effect of financial structure is examined by classifying countries into four categories: financially developed bank based, financially developed stock market based, financially underdeveloped bank based, and financially underdeveloped stock market based systems (see Demirgüç-Kunt and Levine's 2001). The analysis uses a dynamic investment equation including lagged investment, an indicator of financial intermediation, an interaction term between the lag of the growth rate of per capita GDP and a dummy for the financial structure category, and other determinants of investment. A significant

\footnotetext{
${ }^{1}$ Also see Stulz (2001) for a discussion of the links between financial structure and corporate financing. ${ }^{2}$ See Jorgenson (1971) for a survey of the accelerator investment model and other conventional investment theories.
} 
coefficient on the interaction term implies that financial structure affects domestic investment through the accelerator effect.

The paper tests whether financial structure has an independent effect on domestic investment by controlling for the level of financial development using conventional measures of financial intermediation. The effect of financial development on domestic investment are tested using both cross-section and panel data regressions. To circumvent potential simultaneity problems arising from possible two-way relationships between financial intermediation and investment, lags of the financial intermediation indicators are used as instruments in the panel data regressions. In the cross-section regression analysis the initial level of financial development and the country's legal origin are used alternatively as instruments for financial development. The objective is to establish a connection between the exogenous component of financial development and domestic investment and test whether financial structure exerts any incremental effect on domestic investment given the level of financial development.

The key finding in this paper is that the structure of the financial system has no independent effect on investment, in the sense that it does not enhance the response of domestic investment to changes in per capita GDP in a model that accounts for the level of financial development and other determinants of investment. In contrast, the overall level of financial development makes domestic investment more responsive to output growth (accelerator-enhancing effect). The evidence in this paper suggests that it is the 
level of financial development, not the type of financial system that matters for domestic investment.

This paper is an important contribution to the existing body of empirical research on the links between financial intermediation and economic activity. Specifically it sheds some light on the debate on the role of financial structure and complements recent studies that have concluded that financial structure has no effect on long-run economic growth (Levine 2001). This paper focuses on an important aspect of economic activity, namely domestic investment, which plays a substantial role in long-run economic growth. Unlike conventional country case studies which have been used to explore the effects of financial structure on economic performance, this paper exploits cross-country variations in both financial structure and domestic investment.

The remainder of the text is organized as follows. The next section reviews the literature on the role and comparative merits of banks and stock markets in facilitating domestic investment. Section 3 describes the data and presents some summary statistics. Section 4 presents the methodology and discusses the econometric results and section 5 concludes.

\section{Financial Development vs. Financial Structure}

\subsection{Overview}

There are two related but different questions with regard to the impact of financial intermediation on real economic activity. The first question is whether financial 
development affects real economic activity. The second is whether the structure of the financial system matters for real economic outcomes. Empirical research has explored the first question quite extensively. Following the influential work by King and Levine (1993a, 1993b), several empirical studies have provided evidence that strongly supports the view that financial development has a positive effect on various aspects of real economic activity, including investment (Ndikumana 2000; Rajan and Zingales 1998; Demirgüç-Kunt and Maksimovic 1996), employment, productivity, and long run economic growth (Levine, Loayza, and Beck 2000; Beck, Levine, Loayza 2000; Levine and Zervos 1998; Levine 1997). The evidence suggests that the expansion and deepening of the financial system lead to faster economic growth. Without completely settling the

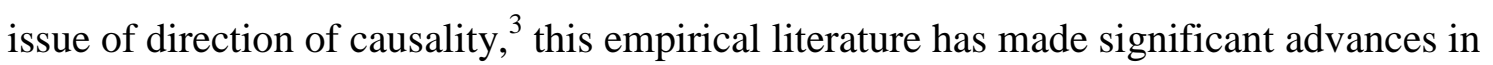
establishing that the exogenous component of financial development has a positive effect on economic growth. The results support the view that financial development leads economic growth.

Until recently, there was relatively less empirical research on the impact of financial structure on economic activity. Historically, the debate over the role of the structure of the financial system for economic activity has revolved around case studies on the comparative merits and disadvantages of banks vs. stock markets in stimulating economic growth. ${ }^{1}$ The research traditionally focused on the comparison between

\footnotetext{
${ }^{3}$ Since Goldsmith $(1958,1969)$ and Patrick (1966) raised the issue of direction of causality between finance and economic growth, arguments have been made in support of both the schumpeterian view of finance as an engine of growth (Schumpeter 1934) and the Robinsonian view of finance as a passive follower of economic growth (Robinson 1952).

${ }^{4}$ See Levine (2001) and Stulz (2001) for a review of this debate, a discussion of its relevance for empirical analysis and policy, and further references on this topic.
} 
countries that have predominantly bank-based financial systems (Germany and Japan) to those that have stock-market-based systems (the United States and England). Studies on Germany and Japan have examined the role of banks' involvement in the ownership and management of corporations and specific roles of bank-firm relationships in the supply of credit, the efficiency of resource allocation, productivity, and overall economic performance. Studies on the United States and England have emphasized such special functions of stock markets as collecting information and facilitating takeovers, and their impact on economic performance. It is difficult to draw general conclusions on the comparative merits of banks vs. stock markets from these case studies, especially given that the four countries most studied (England, Germany, Japan, and the United States) have had similar long-run economic performance.

Recent research has concluded that both banks and stock markets are important for economic performance and that they are complementary. This new research suggests that it is not analytically useful to think in terms of banks vs. stock markets (Levine 2001). Levine (2001) identifies two new approaches in this literature: the financial services view and the law and finance view. The financial services view stresses the role of the financial system in alleviating market imperfections and providing key services to the private sector, thus enhancing economic performance (Merton 1995; Levine 1997). Financial systems improve economic performance by assessing investment opportunities and exerting corporate control, easing risk management, and lowering the costs of resource mobilization (Levine 1997). As financial systems develop, they become more efficient in providing these services, which enhances economic performance. According 
to the financial services view, whether the financial system is predominantly bank based or stock-market based is largely irrelevant for economic outcomes.

The law and finance view, initiated by Laporta, Lopez-de-Silanes, Shleifer, and Vishny $(1998,1997)$, emphasizes the role of creditor and investor rights for financial intermediation. In countries where the legal system enforces these rights effectively, the financial system also becomes more efficient in providing services to the private sector. Consequently, the quality of the legal system is a strong predictor of financial development. Empirically, this view suggests a positive relationship between economic performance and the component of financial development identified by the legal environment. Evidence from cross-country growth analysis supports this view (Levine 1999, 1998; Laporta et al. 1998, 1997). The implication of the law and finance view is that the establishment of an appropriate legal environment will facilitate the development of banks and stock markets, which enhances economic performance. The remainder of this section discusses the role of banks and stock markets in promoting domestic investment.

\subsection{Banks and investment}

Banks can enhance domestic investment in various ways. First, banks increase the amount of funds available for investment by pooling savings. Financial intermediaries are able to economize on the costs of collecting savings from heterogeneous saving units by exploiting economies of scale in information gathering and processing. As a result, for given levels of per capita income and potential saving rate, 
the actual saving and investment rates should be higher in countries that have more developed banking systems (see Pagano 1993).

Second, banks enhance investment by reducing liquidity risk (Diamond and Dybvig 1983; Bencivenga and Smith 1991). Investment often requires the commitment of large amounts of capital for a long time. However, individual savers are reluctant to lend over the long term because they need to maintain a comfortable degree of liquidity in their asset portfolios. Banks can facilitate this trade-off between returns to assets and liquidity by pooling savings, borrowing short term and lending long term. In a country with a poorly developed banking system, profitable investment projects will not be undertaken because of the lack of capital. The development of banks should be accompanied by better allocation of resources and a healthier balance between short-term and long-term investment in the private sector.

Third, financial intermediaries play an important role in reducing the costs of acquiring and processing information about prospective investment activities and in exerting control over the management of existing firms (Diamond 1984). Large firms obtain funds from a diffuse pool of external investors who individually cannot monitor the use of their funds inside the firm. Banks play the role of "delegated monitors" of the behavior of firm managers on the behalf of individual investors. The ability of banks to perform this monitoring function provides more incentives to outside investors to part with their savings and improves the allocation of funds across projects. A developed 
banking system, therefore, should induce higher volumes of investment and more efficient allocation of capital.

Banks specialize in offering customized financial products that are tailored to the needs of individual firms. They are especially the primary source for external finance for investors (borrowers) who have little access to financial markets, such as new and small firms. As Merton (1995: 26) points out, "financial markets tend to be efficient institutional alternatives to intermediaries when the products have standardized terms, can serve a large number of customers, and are well-enough 'understood' for transactors to be comfortable in assessing their prices. As we also know, intermediaries are better suited for low-volume products." Banks are especially important for financing the operation of small firms and the creation of new firms. Evidence shows that small firms in industrialized countries tend to rely more heavily on bank finance than larger firms (Fazzari, Hubbard, and Petersen 1988). Moreover, studies from industrialized countries show that shocks to credit supply by banks (e.g., from monetary policy innovations) have a disproportionately large impact on investment for bank-dependent firms, especially small firms (Gertler and Gilchrist 1994). As a result, we expect a close connection between bank lending and aggregate investment.

Due to their special role of offering customized products, banks are important in financial innovation, that is, the creation of new financial products. Eventually, some of these new products are transferred to financial markets through the "financial innovation spiral" by which banks and financial markets are complementary institutions (Merton 
1995). Banks therefore are important in the Schumpeterian destructive creation process of innovation both in the real sector - by financing innovating entrepreneurs - and in the financial sector - by creating new financial instruments.

Critiques of bank-based systems point to a number of drawbacks and weaknesses of such systems in their ability to enhance investment and economic performance. First, banks may be tempted to extract rent from the information collected on prospective investment projects, thus reducing the payoff that accrues to firms. This may reduce the efforts by firms to undertake innovative activities (Rajan 1992). Second, banks may have a "bias toward prudence." Indeed, evidence from Japan shows that firms with close ties to a "main bank" tend to use innovative technologies less and also have lower profit rates than those without close ties to a "main bank," suggesting that banks extract rent from their relationships with firms (Weinstein and Yafeh 1998; Morck and Nakamura 1999). Third, critiques of bank-based systems argue that close bank-firm relationships may preclude competition in credit markets and reduce banks' ability to enforce efficiency in corporate governance. Morck and Nakamura (1999) present evidence suggesting that banks tend to "prop up" weak firms that belong to bank groups while they promote the interests of creditors when dealing with firms outside of bank groups. Moreover, some studies have shown that while close bank-firm relationships may facilitate access to capital, they do not necessarily reduce the cost of capital nor do they increase investment for firms with close ties to bank groups (Weinstein and Yafeh 1998).

\footnotetext{
${ }^{5}$ A number of studies find that firms with main bank relationships tend to incur higher interest payments. Weinstein and Yafeh (1998: 659) interpret the interest rate differential as a price for liquidity services (higher access to capital) and an "implicit insurance premium" (insurance against bankruptcy) offered by banks to client firms.
} 


\subsection{Stock markets and investment}

The literature contains substantial evidence on a positive correlation between stock market activity and investment. ${ }^{6}$ Barro (1990) concluded that, even after controlling for indicators of future profitability (fundamentals), such as current and past profits, stock market variables have a significant predictive power for investment. The apparent correlation between stock market indicators and aggregate investment raises the important question of how exactly the stock market affects investment.

Researchers have suggested various potential connections between stock market activity and investment. The stock market supplies information about the profitability of investment. As a result, a well-functioning stock market may induce a high level of investment because it can identify fundable projects that otherwise may not be undertaken. The stock market also affects the quality of investment or the allocation of capital by channeling funds to the most profitable investment activities.

Second, the stock market may affect investment through its effects on the cost of capital. As the stock market expands and becomes more liquid, the opportunities for risk sharing expand, which lowers the cost of equity finance. This prediction is supported by evidence that shows that stock market liberalization is accompanied by an increase in aggregate stock market valuation and a decrease in the cost of equity capital (Henry 2000a) and an increase in investment (Henry 2000b).

\footnotetext{
${ }^{6}$ See Morck, Shleifer, and Vishny (1990) for a survey.
} 
Third, the stock market affects investment by exerting pressure on corporate management (Stiglitz 1985), especially through effective takeover or threat of takeover (Jensen and Meckling 1976). As a result, a well-functioning stock market enhances profitability through the process of survival of the fittest in the corporate sector. Stock markets also affect corporate governance by making it easier to tie managerial compensation to firm's performance.

Critiques of stock-market-based systems point to a number of factors that may limit the ability of stock markets to increase the volume and quality of investment. First, the prediction that stock market valuation is a useful guide for investment decisions relies on the assumption that the market valuation of firm's profitability is better than that of the manager of the firm. In the presence of market frictions, such as information asymmetries, or due to speculative behavior, the market valuation of firm's profitability may substantially differ from that of the manager. In this case, which valuation should drive investment decisions? There are diverging views on this question. On one side, some suggest that investment decisions should be based primarily on market valuation (Fischer and Merton 1984). The argument is that to the extent that outside investors are willing to accept a lower rate of return, managers should increase investment up to the point where the rate of return equals the marginal product of capital. On the other side, there are those who argue that the investment decision should be guided by the manager's own valuation of firm's profitability (Bosworth 1975). Under this view, the stock market is simply a "side show" and it does not supply any new useful information that can help mangers in making investment decisions. In this case, so the argument goes, positive 
correlations between investment and stock returns only reflect the econometrician's inability to fully account for economic fundamentals (Morck, Shleifter, and Vishny 1990). Under this view, it is argued that the manager's information set is larger than that of the econometrician, and this could be the only reason why stock returns are correlated with investment. Empirical studies have provided evidence that suggests that the role of the stock market for investment at the firm level is rather limited (see Blanchard, Rhee, and Summers 1993).

Second, while stock markets can facilitate the collect of information on investment opportunities, they also make this information accessible to all market participants. This creates a free-rider problem, which may discourage investors from expending resources to collect information (Stiglitz 1985). In principle, the free-rider problem should be less prominent in bank-based systems since banks reveal less information publicly about individual firms and projects.

Third, while stock markets may facilitate takeovers, critiques argue that this does not necessarily result in higher efficiency. Stock markets do not fully eliminate information asymmetries and insiders may have more information than outsiders (Myers and Majluf 1984). It is therefore difficult for outsiders to outbid insiders. Singh (1975) suggests that takeovers are an imperfect mechanism for economic "natural selection." Using evidence from the United Kingdom, Singh (1997) points out that large firms are able to survive not by improving profitability but by increasing their relative size even further through takeovers. 
Moreover, takeovers do not necessarily result in a net increase in the quantity of investment; they may simply amount to a transfer of wealth from the old residual claimants to the new owners. Evidence from the United States shows that the massive takeover activity that occurred in the 1980s generated neither much net investment nor significant gains in efficiency, but instead left the corporate sector highly leveraged (Crotty and Goldstein 1993).

In the same line of argument, Shleifer and Summers (1988) point out that stock markets may facilitate hostile takeovers that create value for the new owners only by redistributing wealth at the disadvantage of (by extracting rent from) existing stakeholders such as workers and suppliers. These authors argue that hostile takeovers involve a breach of implicit contracts at the detriment of existing stakeholders. Consequently, takeovers have both value-creating and value-redistributing effects and "the latter are likely to be of dominant importance" (Shleifer and Summers 1988: 34). Singh and Weiss (1998) argue that the mechanism of takeovers leads managers to emphasize short-term outcomes at the disadvantage of long-term investment, with negative consequences on macroeconomic performance.

To summarize, the literature has offered an extensive debate on the comparative advantages of banks vs. stock markets for investment. Proponents of bank-based systems emphasize the ability of banks to overcome market frictions, promote long-term investment, and enhance efficiency in the allocation of capital. Proponents of stock 
markets stress the role of stock markets in reducing liquidity risk and exerting corporate control, especially through takeovers. However, history contains no evidence of countries with either well-developed banking systems or large and active stock markets that did not experience high levels of domestic investment and economic growth. ${ }^{\text {D }}$ As Levine (2001) suggests, it may be better to think not in terms of banks vs. stock markets but in terms of banks and stock markets. The analysis in this paper sheds some light on this issue.

\section{Data and Summary Statistics}

This study uses a sample of 99 countries including developing and developed countries for the period 1965-1997. The data are from World Development Indicators; International Financial Statistics; Demirgüç-Kunt and Levine (2001); Beck, DemirgüçKunt, and Levine 2000; and Barth, Caprio, and Levine (2001). Table A1 in the appendix contains a description of the sample. Details on variable definitions and data sources are provided in Table A2 in the appendix.

Because it is difficult to find a comprehensive index of financial intermediation, this study uses various aggregate indicators that have been used in the literature: liquid liabilities, credit to the private sector, net domestic credit, and bank credit, each as percentage of GDP; and the ratio of banks' assets as a percentage of the sum of banks' assets plus the assets of the central bank. Beck, Levine, and Loayza (2000), Levine

\footnotetext{
${ }^{7}$ Commenting on an earlier draft of this paper at a workshop at the Political Economy Research Institute at the University of Massachusetts in October 2000, Professor James Crotty pointed out that financial deepening has historically been associated with increased economic performance, and that financial depth without economic growth is a "historic impossibility."
} 
(1997), and Lynch (1996) discuss issues related to the measurement of financial development.

Following Demirgüç-Kunt and Levine (2001), countries are classified into two categories of financial development: financially developed and financially underdeveloped. A country is classified as financially developed if both its banking sector development (measured by bank credit) and its stock market development (measured by total value of stocks traded as a percentage of GDP) are above the sample averages. To increase the number of countries classified by financial development, the Demirgüç-Kunt and Levine sample is expanded using information from World Development Indicators. This allows us to classify 94 countries as financially developed or financially underdeveloped. Following Demirgüç-Kunt and Levine (2001), countries are further classified into four sub-categories of financial structure: financially developed bank-based, financially developed stock-market-based, financially underdeveloped bankbased, and financially underdeveloped stock-market-based. The developed bank-based and the underdeveloped bank-based form the broad category of bank-based systems, while the developed stock-market based and the underdeveloped stock-market based form the broad category of stock-market based systems. This classification is used to investigate the effects of financial structure on investment.

Table 1 contains some summary statistics for domestic investment and financial indicators. In examining the relationships between financial development and investment, it is important to consider both cross-country variations and within-country 
time series variations to fully capture the dynamics of the interactions. Such an analysis is possible with panel data, which contain both the cross-sectional and time series dimensions. As the statistics in Table 1 show, there are large variations across countries in both investment and financial development (also see Table A3 in the appendix for individual country means) of regression variables. The standard deviation is $8 \%$ for domestic investment (with a mean of $22 \%$ ) and $29 \%$ for liquid liabilities (with a mean of 42\%). The within-country variation adds another $5 \%$ standard deviation for domestic investment and $10 \%$ for liquid liabilities.

\section{[Insert Table 1 about here]}

Table 2 reports the means of the regression variables by financial development and by financial structure category. There are remarkable differences between the financially developed and the financially underdeveloped categories. The financially developed category has higher level and growth rate of income, higher investment, and obviously larger financial development ratios than the financially underdeveloped category. The differences are much less evident across financial structure categories. After controlling for the level of financial development, there are no systematic differences between the two types of financial systems (columns 5-8). Overall, the structure of the financial system does not seem to be a significant distinguishing feature for the level and growth rate of income and investment. This finding is confirmed by the regression results discussed in section 4 below. The data show a positive and statistically significant correlation between domestic investment and all the indicators of financial development, as reported in Table 3.

\section{[Insert Tables 2 and 3 about here]}




\section{Econometric Analysis: Specification and Results}

\subsection{Testing for the effects of financial development on investment \\ a. Panel data regressions}

The first part of the econometric analysis examines whether the exogenous component of financial development has an impact on domestic investment. The analysis is based on a dynamic investment equation that includes an indicator of financial development along with a set of control variables. The dynamic feature of the model arises from the inclusion of lagged investment as a dependent variable. Except for the growth rate of real per capita GDP, the regression variables are in logarithm, which accounts for potential nonlinearities between domestic investment and the explanatory factors. Because of this logarithmic formulation we can interpret the estimated coefficients directly as elasticities.

To circumvent potential simultaneity problems due to possible two-way relationships between financial development and investment, the estimation equation includes the first lag of the financial development indicator. For the same reason, the equation includes the lags of the growth rate of per capita GDP and trade instead of their contemporaneous values. The estimation equation is the following:

$$
\ln I_{i t}=\alpha_{1} \ln I_{i, t-1}+\alpha_{2} \ln F I N_{i, t-1}+\alpha_{3} g_{i, t-1}+\alpha_{4} \ln T R A D E_{i, t-1}+\eta_{i}+u_{i t}
$$

where $I_{i t}$ is the ratio of gross domestic investment to GDP, FIN ${ }_{i t}$ is the indicator of

financial development, $g_{i t}$ is the annual growth rate of real per capita GDP, TRADE $E_{i t}$ is the ratio of the sum of imports and exports to GDP, $\eta_{i}$ is a time-invariant country- 
specific intercept that captures omitted fixed effects, and $u$ is the error term. Five indicators of financial intermediation are entered alternatively in the equation: total liquid liabilities, credit to the private sector, credit by banks, net domestic credit, each as a percentage of GDP, and the share of banks' assets in total assets of financial intermediaries.

The investment equation is estimated as a fixed-effects model. The fixed effects $\left(\eta_{i}\right)$ can be eliminated by first-differencing or by mean-differencing the data following customary practice in panel data econometrics (Wooldridge 2002; Hsiao 1986; Anderson and Hsiao 1982, 1981). This study uses the latter procedure. However, after this transformation, the mean-differenced error term is no longer uncorrelated with the meandifferenced lag of the dependent variable and possibly the other mean-differenced explanatory variables, which creates a bias in the OLS estimates. This problem is circumvented by using an instrumental variable approach with the two-stage least squares procedure, which yields unbiased and consistent least-square dummy variable estimates (see Wooldridge 2002; Arellano and Bover 1995; Hsiao 1986; Anderson and Hsiao 1982, 1981).

The results of the estimation of equation (1) are presented in Table 4. The results show a positive and significant effect of financial development indicators on domestic investment. Since the financial development ratios are entered in logarithm form, the coefficients can be interpreted directly as elasticities of gross domestic investment with respect to the financial development indicators. The sensitivity of domestic investment is 
higher for liquid liabilities and credit to the private sector (with elasticity coefficients of 0.32 and 0.18 , respectively). The coefficients for credit by banks, net domestic credit, and the relative size of banks are not robust to alternative specifications. In the regressions reported in columns 3-5 in Table 4, these three indicators are entered in changes (that is, change in the logarithm of the financial development ratio). When these indicators are entered in levels, as it is the case for liquid liabilities and credit to the private sector, the coefficients are insignificant (not reported for reason of space). One way of interpreting the weakness of the results with these three financial development indicators is that, by their definition, these ratios are not good indicators of the supply of funds for investment purposes. Net domestic credit and credit by banks do not distinguish between credit to the private sector from credit to the public sector. In developing countries especially, the public sector often accounts for a large share of domestic credit demand, a good portion of which is used for government consumption rather than public investment. In such a context, an increase in total domestic credit and credit by banks may have little effect on domestic investment. To measure the effects of financial development on investment, ideally one would use disaggregated indicators that distinguish between credit for investment purposes and credit allocated to consumption, and also between credit to the private sector and credit to the public sector.

\section{[Insert Table 4 about here]}

\section{b. Cross-section regressions}

In addition to panel data regressions, cross-section regressions are performed to test for the long-run relationship between financial development and domestic investment. Each country has one data point consisting of the average of each regression 
variable over the sample period, except for the growth rate of real per capita GDP, which is proxied by the trend growth rate obtained by regressing the logarithm of real per capita GDP on time. The cross-section equation is the following:

$$
\ln I_{i}=\gamma_{0}+\gamma_{1} \ln F_{i}+\gamma_{2} g_{i}+\gamma_{3} \ln T R A D E_{i}+u_{i}
$$

All the variables are defined as in equation (1). Applying the instrumental variable approach allows us to circumvent the problem of the endogeneity of the indicators of financial intermediation, using alternatively the country's legal origin and the initial value of the financial development indicator as instrument for financial development. The legal origin of a country is an exogenous factor which has been demonstrated to be closely correlated with factors that affect a country's financial development (La Porta, Lopez-deSilanes, Shleifer, and Vishny 1998, 1997; Levine 1999, 1998).

The results of cross-section estimation are presented in Table 5. These results indicate a positive and significant effect of financial development indicators on investment. Using the legal origin of the country or initial financial development as instrument for financial development yields similar results, except for credit by banks where the coefficient is insignificant when the initial value of the bank credit to GDP ratio is used as instrument. When the initial values of financial indicators are used as instruments, the coefficients are somewhat smaller in absolute value but their significance improves substantially (see p-values), except for credit by banks.

\section{[Insert Table 5 about here]}

The coefficients on financial development indicators in the cross-section regressions imply a substantial positive long-run elasticity of investment with respect to 
financial development. According to these results, if a country's ratio of liquid liabilities to GDP rises by $10 \%$, its domestic investment to GDP ratio would potentially increase by up to $2.6 \%$. The results therefore indicate that the effect of financial development on investment is economically significant. However, this interpretation must be taken with caution. In practice, financial deepening generates an increase in investment only if a number of other conditions are satisfied. In particular, the economy must be capable of absorbing the increased financial resources (i.e., there must be effective demand for funding) and these resources must effectively be allocated to investment activities.

\subsection{Financial structure vs. financial development: which matters?}

\section{a. Effects of the overall level of financial development}

In this section the investment equation (1) is extended to investigate the effect of the overall financial development and financial structure on domestic investment. The analysis consists of testing whether the overall level of financial development exerts an incremental effect on domestic investment in an equation that includes a time-varying indicator of financial intermediation. There are many ways of exploring this effect. This

study frames the question as follows: does financial development enhance the response of domestic investment to an increase in the demand for output as measured by the growth rate of real per capita GDP? This effect may be called the "accelerator-enhancing" effect of financial development. The accelerator investment theory suggests that an increase in the demand for output is accompanied by an increase in the demand for investment (Jorgenson 1971). The ability of investors to meet such an increase in demand for output 
depends in part on the availability of finance. growth will be larger in countries whose financial systems are more efficient in mobilizing resources and responding to the financing needs of investors. This accelerator-enhancing effect of financial development is tested by including an interaction term between the lag of the growth rate of real per capita GDP and a dummy $F D_{i}$ that equals 1 if a country is classified as financially developed and 0 if it is classified as financially underdeveloped. The estimation equation is the following:

$$
\begin{aligned}
\ln I_{i t}= & \beta_{1} \ln I_{i, t-1}+\beta_{2} \ln F I N_{i, t-1}+\beta_{3} g_{i, t-1}+\beta_{4} F D_{i} * g_{i, t-1} \\
& +\beta_{5} \ln T R A D E_{i, t-1}+\eta_{i}+u_{i t}
\end{aligned}
$$

In this test, the financial development indicator $(F I N)$ is liquid liabilities as a percentage of GDP. The other variables are defined as in equation (1).

The first row in Table 6 (panel a) presents the results of the estimation of equation (3) alternatively with and without liquid liabilities. For expositional convenience, Table 6 reports only the coefficients on the interaction term between the financial development dummy and the lag of the growth rate of real per capita GDP. The full results are reported in Table A4 in the appendix. The results in columns (I) and (II) in Table 6 are obtained using OLS with no fixed effects whereas those in columns (III) and (IV) include fixed effects and are obtained using a two-stage least squares instrumental variable procedure, which produces least squares dummy-variable estimates (LSDV).

\footnotetext{
${ }^{8}$ See Kuh and Meyer (1955) for a discussion of the conditions for the validity of the accelerator investment theory.
} 
The results in panel (a) indicate that the overall level of financial development exerts a positive and significant impact on investment via the accelerator-enhancing effect. This effect is robust to the inclusion of country-specific effects and a time-varying indicator of financial intermediation (liquid liabilities) in the equation.

\section{[Insert Table 6 about here]}

\section{b. Effects of financial structure}

The accelerator-enhancing effect of financial structure is explored by investigating the following empirical question: do stock-market-based financial systems enhance the response of domestic investment to output growth more than bank-based financial systems or vice versa? This question is examined using an investment equation including an interaction term between the lag of output growth and a dummy for the structure of the country's financial system $\left(F S_{i}\right)$ as well as a time-varying indicator of financial intermediation. The equation is the following:

$$
\begin{aligned}
\ln I_{i t}= & \theta_{1} \ln I_{i, t-1}+\theta_{2} \ln F I N_{i, t-1}+\theta_{3} g_{i, t-1}+\theta_{4} F S_{i} * g_{i, t-1} \\
& +\theta_{5} \ln T R A D E_{i, t-1}+\eta_{i}+u_{i t}
\end{aligned}
$$

The ratio of liquid liabilities to GDP is used as indicator of financial intermediation $($ FIN).

First the two broad categories of financial systems, bank-based and stock-marketbased are considered, irrespective of the level of financial development. That is, in each category, there are financially developed and financially underdeveloped countries. The financial system dummy $F S_{i}$ takes the value of 1 if the country's financial system is

\footnotetext{
${ }^{9}$ Ndikumana (2000) finds a positive accelerator-enhancing effect of financial development in a sample of 30 sub-Saharan African countries. This suggests that this result is robust and holds for a variety of samples.
} 
predominantly stock-market based and 0 if it is bank based. If stock-market based financial systems promote investment (through the accelerator-enhancing effect) more than bank-based systems, then the estimate of coefficient $\theta_{4}$ would be positive and significant. $\theta_{4}$ would be negative if bank-based systems promoted investment more than stock market-based systems.

The coefficients of the interaction term between the lag of GDP growth and the dummy for stock-market-based structure ( $\theta_{4}$ in equation 4$)$ are reported in the second row in Table 6 (first row of panel b). When country-specific effects are not taken into account (columns I and II), it appears that financial structure has an impact on investment through the accelerator-enhancing effect. Specifically, a stock-market-based system seems to increase the positive effects of output growth on investment. However, when country-specific effects and an indicator of financial intermediation are included in the regression, financial structure is no longer relevant (column IV); that is, the coefficient on the interaction term between GDP growth and the financial structure dummy (stockmarket based dummy) is still positive but it is no longer statistically significant. The results suggest that whether the financial system is stock-market based or bank based has no incremental effect on domestic investment when financial depth and country-specific effects are accounted for.

Within each broad financial structure category (bank based and stock-market based), the analysis further distinguishes between financially developed and financially underdeveloped countries. There are four categories: developed stock market based, 
developed bank based, underdeveloped stock-market based, and underdeveloped bank based. The objective is to test whether financial structure may have different effects on investment at various levels of financial development. First, two separate regressions are performed, including an interaction term between the lag of GDP growth and a dummy for the stock-market based category in each level of financial development (developed stock-marked based and underdeveloped stock-market based dummies). Second, one regression is performed including dummies for three of the four sub-categories of financial structure simultaneously (one of the four dummies must be left out to avoid collinearity).

Rows [3] and [4] in Table 6 (in panel b) present the results of the regressions including the dummy for the stock-market based category in each level of financial development. The results in row [3] reinforce the findings from the results in row [2]. Even at a high level of financial development, financial structure has no independent effect on domestic investment. The results in rows [2] and [3] suggest that when the level of financial development is controlled for, financial structure has no additional effect on investment. The results indicate that it is the level of financial development, not financial structure, which matters for investment. This conclusion is even stronger at a low level of financial development as the results in row [4] show. When a financial system is underdeveloped, even without accounting for fixed effects, whether it is bank based or stock-market based has no accelerator-enhancing effect on investment. 
In panel (c) of Table 6 (rows 5-7), three of the four dummies for the subcategories of financial structure are entered simultaneously in the regression. The results confirm the conclusion that financial structure has no independent effect on investment in a model that accounts for the level of financial development and country-specific effects.

To summarize, the results in Tables 5 and 6 show that whereas financial development has a positive and robust effect on domestic investment, the structure of the financial system plays no incremental role in explaining cross-country variations in domestic investment. This is the most important new result of this study. This is certainly a potentially controversial finding especially in regard to the debate on the comparative advantages of bank-based vs. stock-market-based financial systems. The result should not be interpreted as implying that stock-market based and bank-based financial systems are identical with respect to their effects on real economic activity. This finding should motivate more research to investigate further the links between financial structure and real economic activity with the aim of identifying the relevant transmission channels, domestic investment being only one of the possible channels.

\section{Conclusion}

This study has examined two related but different questions about the links between financial intermediation and domestic investment. The first question is whether higher financial development induces higher domestic investment. The second is whether the structure of the financial system (bank based vs. stock-market based) matters for domestic investment. The empirical results are informative with regard to both 
questions. The evidence shows that the various indicators of financial development are positively related to domestic investment. This implies that financial development facilitates domestic investment to the extent that it is accompanied by an increase in the supply of funds to investors. This suggests that as a country's financial system becomes more sophisticated, capital becomes more available and cheaper, and it is allocated more efficiently. As a result, investors find it easier to obtain the funds necessary to respond to an increase in the demand for output, which raises the level of investment.

The results in this study also indicate that for a given level of financial development and controlling for country-specific factors, the structure of the financial system has no incremental impact on domestic investment. The results are inconsistent with claims that either bank-based or stock-market-based financial systems are better at promoting investment. The evidence is consistent with the view that banks and stock markets are complementary. This paper contributes to the new empirical literature on the effects of financial structure on long-run economic growth (Levine 2001) and industrylevel performance (Beck and Levine 2002). Whereas these studies focused on long-run growth outcomes, this paper examines both short-run and long-run effects of financial intermediation on domestic investment. The evidence in this paper sheds some light on the debate on the comparative merits of banks vs. stock markets in stimulating investment. Given the wide diversity in the levels of economic development, investment rates, and financial structure across the countries in the sample used in this study, it is not likely that the results are driven by some sampling bias. Moreover, the analysis with panel data is a significant improvement compared to the traditional research on the 
relationship between financial structure and real economic activity, which has typically relied on case studies on industrialized countries.

The results in this paper are informative with regard to policies aimed at boosting domestic investment. The evidence suggests that it may not be useful to expend resources in trying to promote a particular type of financial structure. This is particularly relevant for less-developed countries that are most resource-constrained. Instead, countries will benefit from reducing policy uncertainty, strengthening the regulatory framework, and enforcing creditor and investor rights. This will create an environment that facilitates the development of banks as well as stock markets, which will stimulate domestic investment.

\section{ACKNOWLEDGEMENTS}

The author appreciates financial support from the Political Economy Research Institute at the University of Massachusetts and the Ford Foundation. He is especially grateful for stimulating discussions with and helpful suggestions from Jim Crotty and Carol Heim. He also appreciates comments from anonymous referees on earlier drafts of this paper. 


\section{References}

Anderson, T. W. and C. Hsiao, 1981. "Estimation of dynamic models with error components." Journal of the American Statistical Association 76 (375), 598-606.

Anderson, T. W. and C. Hsiao, 1982. "Formulation and estimation of dynamic models using panel data." Journal of Econometrics 18, 83-114.

Arellano, M. and O. Bover, 1995. "Another look at the instrumental-variable estimation of error-components models." Journal of econometrics 68, 29-52.

Barro, R., 1990. “The stock market and investment." Review of Financial Studies 3(1), 115-131.

Barth, J. R., G. Caprio, and R. Levine, 2001. "Banking systems around the globe: Do regulation and ownership affect performance and stability?" In: F. S. Mishkin (ed.), Prudential Supervision. What Works and What Doesn't. Chicago: University of Chicago Press, pp. 31-88.

Beck, T., A. Demirgüç-Kunt, and R. Levine, 2000. "A new database on financial development and structure." World Bank Economic Review 14 (3), 597-605.

Beck, T. and R. Levine, 2002. "Industry growth and capital allocation: Does having a market- or bank-based system matter?” Journal of Financial Economics 64 (2), 147-80.

Beck, T., R. Levine, and N. Loayza, 2000. "Finance and the sources of growth." Journal of Financial Economics 58, 261-3000.

Bencivenga, V. and B. Smith, 1991. "Financial intermediation and endogenous growth." Review of Economic Studies 58(2), 195-209.

Blanchard, O., R. Changyong, and L. Summers, 1993. "The stock market, profit, and investment." Quarterly Journal of Economics 108, 115-136.

Bosworth, B., 1975. "The stock market and the economy." Brookings Papers on Economic Activity 2, 257-300.

Crotty, J. R. and D. Goldstein, 1993. "Do US financial markets allocate credit efficiently? The case of corporate restructuring in the 1980s.” In: G. A. Dymski, G. Epstein, and R. Pollin (eds.), Transforming the US Financial System. Equity and Efficiency for the $21^{\text {st }}$ Century. New York: M.E. Sharpe, pp. 253-286.

Dermirgüç-Kunt, A. and R. Levine, 2001. "Bank-based and market-based financial system: Cross-country comparisons." In: Dermirgüç-Kunt, A. and R. Levine (eds.), Financial Structure and Economic Growth: A Cross-Country Comparison of Banks, Markets, and Development. Cambridge: MIT Press, pp. 81-140.

Demirgüç-Kunt, A. and V. Maksimovic, 1996. "Stock market development and financing choices of firms." World Bank Economic Review 10 (2), 341-369.

Diamond, D., 1984. "Financial Intermediation and Delegated Monitoring." Review of Economic Studies 51 (3), 393-414.

Diamond, D. and P.. Dybvig, 1983. "Bank Runs, Deposit Insurance and Liquidity." Journal of Political Economy 91 (3), 401-419.

Easterly, W. and H. Yu, 2000. Global Development Network Growth Database. The World Bank.

Fazzari, S. M., G. R. Hubbard, and B. C. Petersen, 1988. "Financing constraints and corporate investment." Brookings Papers on Economic Activity 1, 141-195. 
Fischer, S. and R. Merton, 1984. "Macroeconomics and finance: The role of the stock market." Carnegie Rochester Conference Series on Public Policy 21, 57-108.

Gertler, M. and S. Gilchrist, 1994. "Monetary policy, business cycles and the behavior of small firms," Quarterly Journal of Economics 109 (2), 309-340.

Goldsmith, R. W., 1969. Financial Structure and Development. New Haven: Yale University Press.

Goldsmith, R. W., 1958. Financial Intermediaries in the American Economy Since 1900. Princeton: Princeton University Press.

Henry, P. B., 2000a. "Stock market liberalization, economic reform, and emerging market equity prices." Journal of Finance 54 (2), 529-564.

Henry, P. B., 2000b. "Do stock market liberalizations cause investment booms?" Journal of Financial Economics 58, 301-334.

Hsiao, C., 1986. Analysis of Panel Data. Cambridge University Press, New York.

IMF, International Financial Statistics, CDROM edition (December 1999).

Jensen, M. and W.H. Meckling, 1976. "Theory of the firm: Managerial behavior, agency costs, and ownership structure." Journal of Financial Economics 3, 305-360.

Jorgenson, D. W., 1971. "Econometric Studies of Investment Behavior: A Survey." Journal of Economic Literature 9 (4), 1111-1147.

King, R. G. and R. Levine, 1993a. "Finance, entrepreneurship, and growth. Theory and evidence." Journal of Monetary Economics 32, 513-542.

King, R. G. and R. Levine, 1993b. "Finance and growth: Schumpeter might be right." Quarterly Journal of Economics 108 (3), 717-737

Kuh, E. and J. Meyer, 1955. "Acceleration and related theories of investment: An empirical inquiry." Review of Economics and Statistics 38 (3), 217-230.

La Porta, R., F. Lopez-de-Silanes, A. Shleifer, and R. Vishny, 1998. "Law and finance." Journal of Political Economy 106 (6), 113-1155.

La Porta, R., F. Lopez-de-Silanes, A. Shleifer, and R. Vishny, 1997. "Legal determinants of external finance." Journal of Finance 52 (3), 1131-1150.

Levine, R., 2001. "Bank-based or market-based financial systems: Which is better?" Carlson School of Management, University of Minnesota, working paper WP005, forthcoming in Journal of Financial Intermediation, 2003.

Levine, R., 1999. “Law, finance, and economic growth.” Journal of Financial Intermediation 8 (1/2), 8-36.

Levine, R., 1998. "The legal environment, banks, and long-run economic growth." Journal of Money, Credit, and Banking 30 (3), 598-613.

Levine, R., 1997. "Financial Development and Economic Growth: Views and Agenda." Journal of Economic Literature 35, 688-726.

Levine, R., N. Loayza, and T. Beck, 2000. "Financial intermediation and growth: Causality and Causes." Journal of Monetary Economics 46, 31-77.

Levine, R. and S. Zervos, 1998. "Stock markets, banks, and economic growth" American Economic Review 88, 537-558.

Lynch, D., 1996. "Measuring financial sector development: A study of selected AsiaPacific countries." Developing Economies 32 (1), 3-33.

Merton, R., 1995. "A functional perspective of financial intermediation." Financial Management 24, 23-41. 
Morck, R. and M. Nakamura, 1999. "Banks and corporate control in Japan." Journal of Finance 54, 319-340.

Morck, R., A. Shleifer, and R. Vishny, 1990. "The stock market and investment: Is the stock market a sideshow?" Brookings Papers on Economic Activity 2, 157-215.

Myers, S. and N. Majluf, 1984. "Corporate financing and investment decisions when firms have information that investors do not have." Journal of Financial Economics 13, 187-221.

Ndikumana, L., 2000. "Financial determinants of domestic investment in sub-Saharan Africa: Evidence from panel data." World Development 28 (2), 381-400.

Pagano, M., 1993. "Financial markets and growth. An overview." European Economic Review 39, 613-622.

Patrick, H. T., 1966. "Financial Development and Economic Growth in Underdeveloped Countries." Economic Development and Cultural Change 14, 174-189.

Rajan, R., 1992. "Insiders and outsiders: The choice between informed and arms length debt." Journal of Finance 47 (4), 1367-1400.

Rajan, R. and L. Zingales, 1998. "Financial dependence and growth." American Economic Review 88 (3), 559586.

Robinson, J., 1952. The role of Interest and Other Essays. London: Macmillan.

Schumpeter, J. A., 1934. The Theory of Economic Development. Cambridge Harvard University Press.

Shleifer, A. and L. Summers, 1988. "Breach of trust in hostile takeovers." In: A. Auerbach (ed.), Corporate Takeovers: Causes and Consequences. Chicago: University of Chicago Press, pp. 33-56.

Singh, A., 1975. "Takeovers, economic natural selection, and the theory of the firm: Evidence from the postwar United Kingdom experience." The Economic Journal 85, 497-515.

Singh, A., 1997. "Financial liberalization, stock markets and economic development." The Economic Journal 107, 771-782.

Singh, A. and B. Weiss, 1998. "Emerging stock markets, portfolio capital flows and longterm economic growth: Micro and macroeconomic perspectives." World Development 26 (4), 607-622.

Stiglitz, J., 1985. "Credit markets and the control of capital." Journal of Money, Credit and Banking 17 (2), 133-152.

Stulz, R. 2001. "Does financial structure matter for economic growth? A corporate finance perspective." In: Dermirgüç-Kunt, A. and R. Levine (eds.), Financial Structure and Economic Growth: A Cross-Country Comparison of Banks, Markets, and Development. Cambridge: MIT Press, pp. 81-140.

Weinstein, D. and Y. Yafeh, 1998. "On the cost of bank-centered financial system: Evidence from the changing main bank relations in Japan." Journal of Finance, 53 (2), 635-672.

Wooldridge, J. M., 2002. Econometric Analysis of Cross Section and Panel Data. Cambridge: MIT Press.

World Bank 1999. World Development Indicators (CDROM edition). 
Table 1: Sample summary statistics (simple averages)

\begin{tabular}{l|cccccc}
\hline & $\begin{array}{c}\text { Gross } \\
\text { domestic } \\
\text { investment }\end{array}$ & $\begin{array}{c}\text { Liquid } \\
\text { liabilities }\end{array}$ & $\begin{array}{c}\text { Credit to } \\
\text { private } \\
\text { sector }\end{array}$ & $\begin{array}{c}\text { Credit by } \\
\text { banks }\end{array}$ & $\begin{array}{c}\text { Net } \\
\text { domestic } \\
\text { credit }\end{array}$ & $\begin{array}{c}\text { Banks / } \\
\text { (banks + } \\
\text { central } \\
\text { bank) } \\
\text { assets }\end{array}$ \\
\hline $\begin{array}{l}\text { Sample } \\
\text { mean }\end{array}$ & 22.05 & 42.50 & 34.84 & 48.89 & 43.14 & 77.22 \\
$\begin{array}{l}\text { Sample } \\
\text { median }\end{array}$ & 21.60 & 34.14 & 25.39 & 38.93 & 34.48 & 82.91 \\
$\begin{array}{l}\text { Cross- } \\
\text { country } \\
\text { standard } \\
\text { deviation }\end{array}$ & 8.46 & 29.52 & 29.91 & 40.56 & 34.03 & 20.77 \\
$\begin{array}{l}\text { Within- } \\
\text { country } \\
\text { standard } \\
\text { deviation }\end{array}$ & 5.29 & 10.47 & 12.20 & 18.56 & & \\
\hline
\end{tabular}

Sources: Author's computation using data from: World Bank, World Development Indicators 1999; and IMF, International Financial Statistics, December 1999. 
Table 2: Summary statistics (simple averages) by financial development and financial structure category

\begin{tabular}{|c|c|c|c|c|c|c|c|c|}
\hline \multirow[b]{3}{*}{1997 GDP per capita } & \multicolumn{2}{|c|}{ Financial development } & \multicolumn{2}{|c|}{ Financial structure } & \multicolumn{4}{|c|}{ Financial development and financial structure } \\
\hline & Developed & $\begin{array}{l}\text { Under- } \\
\text { developed }\end{array}$ & $\begin{array}{l}\text { Bank- } \\
\text { based }\end{array}$ & $\begin{array}{l}\text { Stock } \\
\text { market- } \\
\text { based }\end{array}$ & $\begin{array}{l}\text { Developed } \\
\text { bank- } \\
\text { based }\end{array}$ & $\begin{array}{l}\text { Developed } \\
\text { stock } \\
\text { market- } \\
\text { based }\end{array}$ & $\begin{array}{l}\text { Under- } \\
\text { developed } \\
\text { bank- } \\
\text { based }\end{array}$ & $\begin{array}{l}\text { Under- } \\
\text { developed } \\
\text { stock } \\
\text { market- } \\
\text { based }\end{array}$ \\
\hline & 20615 & 2480 & 10906 & 14971 & 21045 & 20148 & 3153 & 7207 \\
\hline GDP growth 1965-1997 & 2.88 & 1.21 & 2.38 & 2.48 & 2.75 & 3.01 & 2.12 & 1.57 \\
\hline $\begin{array}{l}\text { Gross domestic } \\
\text { investment ( } \% \text { of GDP) }\end{array}$ & 25.52 & 20.51 & 23.24 & 24.20 & 25.64 & 25.38 & 21.51 & 22.45 \\
\hline $\begin{array}{l}\text { Liquid liabilities (\% of } \\
\text { GDP) }\end{array}$ & 70.99 & 29.83 & 52.26 & 53.48 & 71.07 & 68.75 & 37.41 & 32.64 \\
\hline $\begin{array}{l}\text { Credit to private sector } \\
\text { (\% of GDP) }\end{array}$ & 67.70 & 21.46 & 42.86 & 55.16 & 64.32 & 71.84 & 25.84 & 29.91 \\
\hline $\begin{array}{c}\text { Banks assets / (banks }+ \\
\text { central bank assets) }\end{array}$ & 90.64 & 71.95 & 82.11 & 84.43 & 89.33 & 92.32 & 76.68 & 73.6 \\
\hline $\begin{array}{l}\text { Net domestic credit (\% } \\
\text { of GDP) }\end{array}$ & 70.93 & 29.73 & 52.32 & 55.60 & 74.13 & 67.02 & 34.88 & 38.31 \\
\hline Bank credit (\% of GDP) & 84.52 & 32.32 & 59.66 & 68.11 & 84.88 & 84.07 & 39.65 & 43.96 \\
\hline Trade (\% of GDP) & 74.77 & 58.48 & 60.70 & 66.60 & 69.37 & 80.98 & 67.58 & 54.5 \\
\hline
\end{tabular}

Sources: Author's computation using data from: World Bank, World Development Indicators 1999; and IMF, International Financial Statistics, December 1999. 
Table 3. Correlation between domestic investment and financial indicators

\begin{tabular}{|c|c|c|c|c|c|}
\hline Variables & $\begin{array}{l}\text { Liquid } \\
\text { liabilities }\end{array}$ & $\begin{array}{l}\text { Credit to } \\
\text { private } \\
\text { sector }\end{array}$ & $\begin{array}{l}\text { Credit by } \\
\text { banks }\end{array}$ & $\begin{array}{l}\text { Net } \\
\text { domestic } \\
\text { credit }\end{array}$ & $\begin{array}{l}\text { Banks assets / } \\
\text { total assets }\end{array}$ \\
\hline $\begin{array}{l}\text { Gross domestic } \\
\text { investment }\end{array}$ & $\begin{array}{r}0.523 \\
0.0001 \\
98\end{array}$ & $\begin{array}{r}0.428 \\
0.0001 \\
99\end{array}$ & $\begin{array}{r}0.355 \\
0.0003 \\
99\end{array}$ & $\begin{array}{r}0.322 \\
0.0011 \\
99\end{array}$ & $\begin{array}{r}0.450 \\
0.0001 \\
96\end{array}$ \\
\hline $\begin{array}{l}\text { Liquid } \\
\text { liabilities }\end{array}$ & & $\begin{array}{r}0.836 \\
0.0001 \\
98\end{array}$ & $\begin{array}{r}0.819 \\
0.0001 \\
98\end{array}$ & $\begin{array}{r}0.781 \\
0.0001 \\
98\end{array}$ & $\begin{array}{r}0.429 \\
0.0001 \\
95\end{array}$ \\
\hline $\begin{array}{l}\text { Credit to } \\
\text { private sector }\end{array}$ & & & $\begin{array}{r}0.863 \\
0.0001 \\
99\end{array}$ & $\begin{array}{r}0.772 \\
0.0001 \\
99\end{array}$ & $\begin{array}{r}0.543 \\
0.0001 \\
96\end{array}$ \\
\hline Credit by banks & & & & $\begin{array}{r}0.948 \\
0.0001 \\
99\end{array}$ & $\begin{array}{r}0.311 \\
0.0021 \\
96\end{array}$ \\
\hline $\begin{array}{l}\text { Net domestic } \\
\text { credit }\end{array}$ & & & & & $\begin{array}{r}0.250 \\
0.014 \\
96 \\
\end{array}$ \\
\hline
\end{tabular}

Note: The first number in each cell is the coefficient of correlation, the second is the pvalue, and the third is the number of observations (equal to the number of countries). 
Table 4: Effects of financial development on domestic investment: Regressions with fixed effects (LSDV)

\begin{tabular}{|c|c|c|c|c|c|c|c|c|c|c|}
\hline \multirow[t]{2}{*}{ Explanatory variables } & \multicolumn{2}{|c|}{$\begin{array}{l}\text { [1] With liquid } \\
\text { liabilities }\end{array}$} & \multicolumn{2}{|c|}{$\begin{array}{l}\text { [2] With credit to } \\
\text { private sector }\end{array}$} & \multicolumn{2}{|c|}{$\begin{array}{l}\text { [3] With credit by } \\
\text { banks }\end{array}$} & \multicolumn{2}{|c|}{$\begin{array}{l}\text { [4] With net } \\
\text { domestic credit }\end{array}$} & \multicolumn{2}{|c|}{$\begin{array}{l}\text { [5] With commercial } \\
\text { banks assets share }\end{array}$} \\
\hline & $\begin{array}{r}\text { Coefficient } \\
\text { (p-value) }\end{array}$ & $\begin{array}{r}1^{\text {st }} \\
\text { stage } \\
\text { F-test }^{\mathrm{a}}\end{array}$ & $\begin{array}{r}\text { Coefficient } \\
\text { (p-value) }\end{array}$ & $\begin{array}{r}1^{\text {st }} \\
\text { stage } \\
\text { F-test }\end{array}$ & $\begin{array}{r}\text { Coefficient } \\
\text { (p-value) }\end{array}$ & $\begin{array}{r}1^{\text {st }} \\
\text { stage } \\
\text { F-test }\end{array}$ & $\begin{array}{r}\text { Coefficient } \\
\text { (p-value) }\end{array}$ & $\begin{array}{r}1^{\text {st }} \\
\text { stage } \\
\text { F-test }\end{array}$ & $\begin{array}{r}\text { Coefficient } \\
\text { (p-value) }\end{array}$ & $\begin{array}{r}1^{\mathrm{st}} \\
\text { stage } \\
\text { F-test }\end{array}$ \\
\hline Liquid liabilities & $\begin{array}{r}0.316 \\
(0.0005)\end{array}$ & 24.2 & & & & & & & & \\
\hline Credit to private sector & & & $\begin{array}{l}0.179 \\
(0.05)\end{array}$ & 27.1 & & & & & & \\
\hline Credit by banks & & & & & $\begin{array}{l}0.090 \\
(0.04)\end{array}$ & 21.7 & & & & \\
\hline Net domestic credit & & & & & & & $\begin{array}{l}0.099 \\
(0.05)\end{array}$ & 10.8 & & \\
\hline $\begin{array}{l}\text { Commercial banks assets } \\
\text { share }\end{array}$ & & & & & & & & & $\begin{array}{l}0.069 \\
(0.03)\end{array}$ & 4.2 \\
\hline Lagged investment & $\begin{array}{r}0.615 \\
(0.0001)\end{array}$ & 397.6 & $\begin{array}{r}0.609 \\
(0.0001)\end{array}$ & 359.5 & $\begin{array}{r}0.367 \\
(0.0001)\end{array}$ & 54.3 & $\begin{array}{r}0.364 \\
(0.0001)\end{array}$ & 73.5 & $\begin{array}{r}0.849 \\
(0.0001)\end{array}$ & 70.6 \\
\hline Output growth & $\begin{array}{r}0.0029 \\
(0.04)\end{array}$ & 257.9 & $\begin{array}{r}0.0032 \\
(0.02)\end{array}$ & 232.3 & $\begin{array}{r}0.0091 \\
(0.0001)\end{array}$ & 10.9 & $\begin{array}{r}0.0091 \\
(0.0001)\end{array}$ & 318.2 & $\begin{array}{r}0.0056 \\
(0.0001)\end{array}$ & 307.6 \\
\hline Trade & $\begin{array}{r}0.306 \\
(0.0001)\end{array}$ & 117.2 & $\begin{array}{r}0.297 \\
(0.0008)\end{array}$ & 105.3 & $\begin{array}{r}0.222 \\
(0.0001)\end{array}$ & 32.8 & $\begin{array}{r}0.229 \\
(0.0001)\end{array}$ & 16.9 & $\begin{array}{r}0.226 \\
(0.0001)\end{array}$ & 16.6 \\
\hline Adj. $R^{2}$ & 0.363 & & 0.370 & & 0.119 & & 0.117 & & 0.297 & \\
\hline $\begin{array}{l}\text { Overidentifying } \\
\text { restrictions F-test }^{\mathrm{b}}\end{array}$ & $\begin{array}{r}1.38 \\
(0.24)\end{array}$ & & $\begin{array}{r}1.29 \\
(0.27)\end{array}$ & & $\begin{array}{r}1.81 \\
(0.12)\end{array}$ & & $\begin{array}{r}1.82 \\
(0.12)\end{array}$ & & $\begin{array}{r}1.78 \\
(0.13)\end{array}$ & \\
\hline Observations & 2756 & & 2779 & & 2771 & & 2756 & & 2584 & \\
\hline Countries & 98 & & 99 & & 99 & & 99 & & 96 & \\
\hline
\end{tabular}

The dependent variable is the logarithm of gross domestic investment as percentage of GDP. The p-values are given in parenthesis. The explanatory variables are in logarithm (except for output growth) and they are lagged once. In the regressions [3]-[5], the financial development variables are entered in changes; the coefficients on the financial variables are insignificant when they are entered in levels. 
${ }^{\text {a }}$ F-test of the (first-stage) regression of lagged regressors (endogenous) on all instruments. The null hypothesis is that the coefficients on the instruments are jointly zero. The p-values are less than 0.0001 in all the regressions.

${ }^{\mathrm{b}}$ Test for overidentifying restrictions (p-values are in parenthesis). The null hypothesis is that the instruments are not correlated with the error term; in all the regressions this hypothesis cannot be rejected, supporting the validity of the instruments. 
Table 5: Effects of financial development on domestic investment: Cross-section regressions

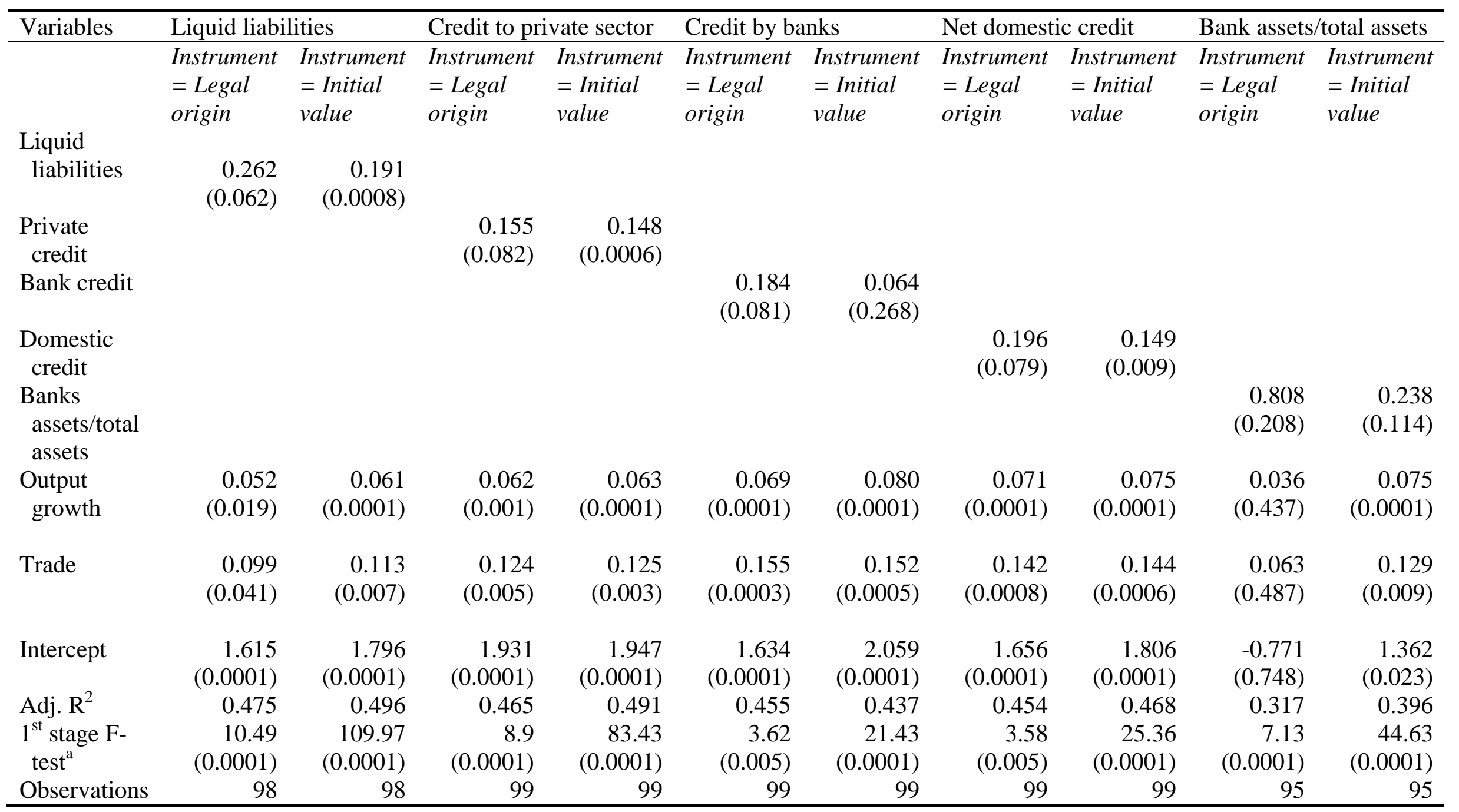


The dependent variable is the logarithm of average gross domestic investment as percentage of GDP. The p-values are given in parenthesis.

${ }^{a}$ F-test of the (first-stage) regression of the financial development indicator in the column on all instruments (all exogenous variables). The null hypothesis is that the coefficients are jointly zero. The p-values are in parenthesis. 
Table 6: Effects of financial structure vs. financial development on domestic investment: Accelerator enhancing effect (Coefficient on the GROWTH*STRUCTURE/DEVELOPMENT interaction term)

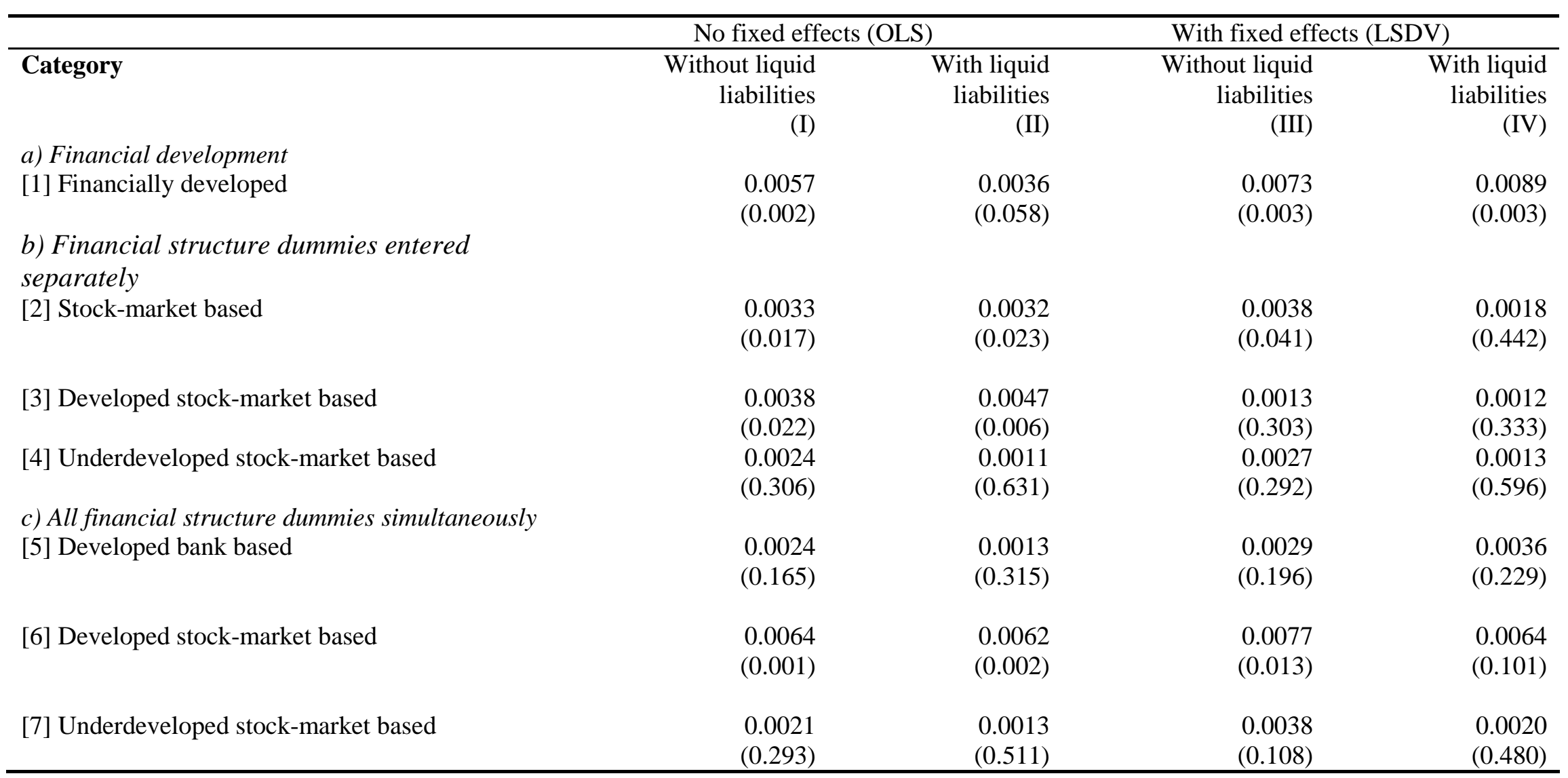

The dependent variable is the logarithm of average gross domestic investment as percentage of GDP. The p-values are given in parenthesis. Only the coefficients on the interaction between the financial structure/development category dummy and lagged output growth (measuring the accelerator-enhancing effect) are reported. The other regressors included in the equation are the lags of domestic investment, output growth, and trade; the regressions in columns (II) and (IV) include lagged liquid liabilities as well. The full results are reported in Table A4 in the appendix. 


\section{APPENDIX TABLES}

Table A1: Sample description: classification by legal origin and financial structure

\begin{tabular}{|c|c|c|c|c|}
\hline \multicolumn{5}{|c|}{ Classification by legal origin } \\
\hline $\begin{array}{l}\text { British law } \\
(n=34)\end{array}$ & $\begin{array}{l}\text { French law } \\
(n=56)\end{array}$ & & $\begin{array}{l}\text { German law } \\
(n=4)\end{array}$ & $\begin{array}{l}\text { Scandinavian law } \\
(n=5)\end{array}$ \\
\hline Australia & Algeria & Iran & Austria & Denmark \\
\hline Bangladesh & Argentina & Italy & Japan & Finland \\
\hline Barbados & Belgium & Jordan & Korea & Iceland \\
\hline Botswana & Benin & Madagascar & Switzerland & Norway \\
\hline Canada & Bolivia & Mali & & Sweden \\
\hline Cyprus & Brazil & Malta & & \\
\hline Fiji & Burkina & Mauritania & & \\
\hline Gambia & Faso & Mauritius & & \\
\hline Ghana & Burundi & Mexico & & \\
\hline Guyana & Cameroon & Morocco & & \\
\hline India & Central & Netherlands & & \\
\hline Ireland & African & Nicaragua & & \\
\hline Israel & Republic & Niger & & \\
\hline Jamaica & Chad & Panama & & \\
\hline Kenya & Chile & Paraguay & & \\
\hline Lesotho & Colombia & Peru & & \\
\hline Malawi & Congo Dem. & Philippines & & \\
\hline Malaysia & Rep. & Portugal & & \\
\hline Nepal & Congo Dem. & Rwanda & & \\
\hline New Zealand & Rep. & Senegal & & \\
\hline Nigeria & Congo Rep. & Seychelles & & \\
\hline Pakistan & Costa Rica & Spain & & \\
\hline Papua New & Côte & Tunisia & & \\
\hline Guinea & d'Ivoire & Turkey & & \\
\hline Singapore & Dominican & Uruguay & & \\
\hline South Africa & Republic & Venezuela & & \\
\hline Sri Lanka & Ecuador & & & \\
\hline Sudan & Egypt & & & \\
\hline Swaziland & El Salvador & & & \\
\hline Thailand & France & & & \\
\hline Trinidad and & Gabon & & & \\
\hline Tobago & Greece & & & \\
\hline United & Guatemala & & & \\
\hline Kingdom & Haiti & & & \\
\hline United States & Honduras & & & \\
\hline Zambia & Indonesia & & & \\
\hline Zimbabwe & & & & \\
\hline
\end{tabular}


Table A1 (continued): Sample description

\begin{tabular}{llll}
\hline Classification by financial structure & & \\
\hline $\begin{array}{l}\text { Developed } \\
\text { bank based } \\
(n=15)\end{array}$ & $\begin{array}{l}\text { Developed stock } \\
\text { market based }(n=12)\end{array}$ & $\begin{array}{l}\text { Underdeveloped } \\
\text { bank based } \\
(n=19)\end{array}$ & $\begin{array}{l}\text { Underdeveloped stock } \\
\text { market based } \\
(n=8)\end{array}$ \\
Austria & Australia & Argentina & Brazil \\
Belgium & Canada & Bangladesh & Chile \\
Cyprus & Korea & Barbados & Denmark \\
Finland & Malaysia & Colombia & Jamaica \\
France & Netherlands & Costa Rica & Mexico \\
Israel & Singapore & Ecuador & Peru \\
Italy & South Africa & Egypt & Philippines \\
Japan & Sweden & Greece & Turkey \\
Jordan & Switzerland & Honduras & \\
New Zealand & Thailand & India & \\
Norway & United Kingdom & Indonesia & \\
Panama & United States & Ireland & \\
Portugal & & Kenya & \\
Spain & & Mauritius & \\
Tunisia & & Nepal & \\
& & Pakistan & \\
& & Sri Lanka & \\
& & Trinidad and Tobago & \\
& & Venezuela & \\
\hline
\end{tabular}


Table A1 (end): Sample description

\begin{tabular}{llll}
\hline Classification by financial development (5 countries not classified) & \\
\hline Financially developed $(n=27)$ & $\begin{array}{l}\text { Financially } \text { underdeveloped } \\
(n=67)\end{array}$ & \\
& & & \\
Australia & Algeria & Ghana & Peru \\
Austria & Argentina & Greece & Philippines \\
Belgium & Bangladesh & Guatemala & Rwanda \\
Canada & Barbados & Guyana & Senegal \\
Cyprus & Benin & Haiti & Seychelles \\
Finland & Bolivia & Honduras & Sri Lanka \\
France & Botswana & Iceland & Sudan \\
Israel & Brazil & India & Swaziland \\
Italy & Burkina Faso & Indonesia & Syria \\
Japan & Burundi & Iran. & Togo \\
Jordan & Cameroon & Ireland & Trinidad and \\
Korea & Central African & Jamaica & Tobago \\
Malaysia & Republic & Kenya & Turkey \\
Netherlands & Chad & Lesotho & Uruguay \\
New Zealand & Chile & Madagascar & Venezuela \\
Norway & Colombia & Malawi & Zambia \\
Panama & Congo Dem. Rep. & Mali & Zimbabwe \\
Portugal & Congo Rep. & Malta & \\
Singapore & Costa Rica & Mauritania & \\
South Africa & Côte d'Ivoire & Mauritius & \\
Spain & Denmark & Mexico & \\
Sweden & Dominican & Morocco & \\
Switzerland & Republic & Nepal & \\
Thailand & Ecuador & Nicaragua & \\
Tunisia & Egypt & Niger & \\
United Kingdom & El Salvador & Nigeria & \\
United States & Fiji & Pakistan & \\
& Gabon & Papua New Guinea & \\
& Gambia & Paraguay & \\
\hline & & & \\
& & & \\
& & &
\end{tabular}

Notes: Classification by income level: 33 countries as low income; 25 as lower middle income; 16 as upper middle income; 4 as high income non-OECD; 21 as high income OECD.

Classification by region: 31 countries in sub-Saharan Africa; 23 in Latin America; 15 in Western Europe; 11 in East Asia; 11 in Middle East and North Africa; 2 in North America; 1 in East Europe and Central Asia.

Sources: Dermirgüç-Kunt, A. and R. Levine, 2001. "Bank-based and market-based financial system: Cross-country comparisons.” In: Dermirgüç-Kunt, A. and R. Levine (eds.), Financial structure and Economic Growth: A Cross-Country Comparison of Banks, Markets, and Development. Cambridge: MIT Press, pp. 81-140; Easterly, W. and H. Yu, 2000. Global Development Network Growth Database. World Bank. 
Table A2. Variables and data sources

\begin{tabular}{|c|c|c|}
\hline Variable name & Source & Description \\
\hline $\begin{array}{l}\text { Gross domestic } \\
\text { investment }\end{array}$ & $\begin{array}{l}\text { World Development } \\
\text { Indicators } 1999 \\
\text { (WDI99) }\end{array}$ & $\%$ of GDP \\
\hline $\begin{array}{l}\text { Real per capita } \\
\text { GDP }\end{array}$ & WDI99 & Constant 1995 US dollars \\
\hline TRADE & WDI99 & TRADE = Imports + Exports, $\%$ of GDP \\
\hline Liquid liabilities & WDI99 & $\begin{array}{l}\text { Liquid liabilities of financial intermediaries = } \\
\text { M3 as \% of GDP }\end{array}$ \\
\hline $\begin{array}{l}\text { Credit to the } \\
\text { private sector }\end{array}$ & WDI99 & $\%$ of GDP \\
\hline $\begin{array}{l}\text { Net domestic } \\
\text { credit }\end{array}$ & WDI99 & $\%$ of GDP \\
\hline Credit by banks & WDI99 & $\%$ of GDP \\
\hline $\begin{array}{l}\text { Banks - Central } \\
\text { Bank }\end{array}$ & $\begin{array}{l}\text { International } \\
\text { Financial Statistics, } \\
\text { December } 1999\end{array}$ & $\begin{array}{l}\text { Commercial banks' assets as \% of the sum of } \\
\text { commercial banks' assets plus central bank's } \\
\text { assets. } \\
\text { Commercial banks' assets = line } 22+\text { line } 22 \mathrm{~b} \\
+ \text { line } 22 \mathrm{c}+\text { line } 22 \mathrm{~d} \text {. } \\
\text { Central bank's assets = line } 12 \mathrm{a}+\text { line } 12 \mathrm{~b}+ \\
\text { line } 12 \mathrm{c}+\text { line } 12 \mathrm{~d} \text {. }\end{array}$ \\
\hline $\begin{array}{l}\text { Total value } \\
\text { traded }\end{array}$ & WDI99 & $\%$ of GDP \\
\hline $\begin{array}{l}\text { Indicator of } \\
\text { financial } \\
\text { structure }\end{array}$ & $\begin{array}{l}\text { Demirgüç-Kunt and } \\
\text { Levine (2001). }\end{array}$ & $\begin{array}{l}\text { Classification of countries as developed bank- } \\
\text { based, developed stock market-based, } \\
\text { underdeveloped bank-based, underdeveloped } \\
\text { stock market-based. }\end{array}$ \\
\hline Legal origin & $\begin{array}{l}\text { Easterly and } \mathrm{Yu} \\
\text { (2000) Global } \\
\text { Development } \\
\text { Network Growth } \\
\text { Database }\end{array}$ & From sheet: "fixed factors" \\
\hline
\end{tabular}


Table A3: GDP, investment, and financial indicators, average 1965-1997

\begin{tabular}{|c|c|c|c|c|c|c|c|c|}
\hline Country & $\begin{array}{l}\text { GDP } \\
\text { per } \\
\text { capita } \\
1997\end{array}$ & $\begin{array}{l}\text { Gross } \\
\text { domestic } \\
\text { investment } \\
(\% G D P)\end{array}$ & $\begin{array}{l}\text { Liquid } \\
\text { liabilities } \\
(\% \\
G D P)\end{array}$ & $\begin{array}{l}\text { Credit } \\
\text { to } \\
\text { private } \\
\text { sector } \\
(\% G D P)\end{array}$ & $\begin{array}{l}\text { Credit } \\
\text { by banks } \\
(\% G D P)\end{array}$ & $\begin{array}{l}\text { Net } \\
\text { Domestic } \\
\text { Credit } \\
(\% \\
G D P)\end{array}$ & $\begin{array}{l}\text { Banks } \\
\text { assets } \\
(\% \\
\text { total })\end{array}$ & $\begin{array}{l}\text { Trade } \\
(\% \\
G D P)\end{array}$ \\
\hline Algeria & 1480 & 33.7 & 61.8 & 36.1 & 62.0 & 62.0 & 78.0 & 52.6 \\
\hline Argentina & 8955 & 21.5 & 21 & 19.1 & 30.7 & 27 & 76.3 & 14.4 \\
\hline Australia & 20619 & 24.3 & 52.7 & 53.2 & 67.3 & 53.8 & 93.6 & 33.0 \\
\hline Austria & 30320 & 26.1 & 73.9 & 71.1 & 90.4 & 90.4 & 98.7 & 67.7 \\
\hline Bangladesh & 338 & 17.4 & 20.4 & 11.8 & 21.2 & 21.2 & 87.0 & 18.1 \\
\hline Barbados & NA & 20.2 & 51.3 & 40.6 & 45.2 & 42.8 & 91.8 & 121.5 \\
\hline Belgium & 28006 & 20.1 & 53.7 & 32.5 & 72.5 & 72.5 & 92.3 & 116.9 \\
\hline Benin & 387 & 14.8 & 19.8 & 17.0 & 16.7 & 16.7 & 87.7 & 56.8 \\
\hline Bolivia & 938 & 15.6 & 26.5 & 26.4 & 33.3 & 31.4 & 37.2 & 48.2 \\
\hline Botswana & 3420 & 30.8 & 24.2 & 13.1 & -25.2 & -25.2 & NA & 90.5 \\
\hline Brazil & 4562 & 21.3 & 30.2 & 42.8 & 59.4 & 47.3 & 66.2 & 16.6 \\
\hline $\begin{array}{c}\text { Burkina } \\
\text { Faso }\end{array}$ & 251 & 19.2 & 15.9 & 11.5 & 9.5 & 9.5 & 89.9 & 35.6 \\
\hline Burundi & 143 & 11.4 & 15.1 & 9.6 & 16.9 & 14.7 & 54.2 & 30.7 \\
\hline Cameroon & 631 & 19.5 & 18.4 & 19.5 & 20.9 & 20.9 & 87.7 & 47.5 \\
\hline Canada & 20208 & 22.2 & 62.4 & 61.1 & 69.9 & 50.0 & 90.5 & 50.9 \\
\hline $\begin{array}{l}\text { Central } \\
\text { African } \\
\text { Republic }\end{array}$ & 346 & 13.4 & 17.5 & 11.5 & 17.7 & 17.7 & 69.5 & 55.6 \\
\hline Chad & 222 & 7.4 & 12.1 & 9.7 & 13.6 & 13.5 & 77.2 & 42.2 \\
\hline Chile & 4666 & 19.9 & 29.8 & 38 & 57.5 & 57.0 & 53.9 & 46.1 \\
\hline Colombia & 2115 & 19.1 & 25.3 & 25.8 & 31.6 & 22.5 & 80.0 & 29.8 \\
\hline $\begin{array}{l}\text { Congo, } \\
\text { Dem Rep. }\end{array}$ & 127 & 12.1 & 12.5 & 2.4 & 10.7 & 10.7 & 28.3 & 38.9 \\
\hline $\begin{array}{l}\text { Congo, } \\
\text { Rep. }\end{array}$ & 815 & 31.1 & 17.4 & 16.8 & 23.1 & 23.1 & 79.3 & 103.1 \\
\hline Costa Rica & 2672 & 24.2 & 34.9 & 21.5 & 32.8 & 31.7 & 68.8 & 71.5 \\
\hline $\begin{array}{l}\text { Côte } \\
\text { d'Ivoire }\end{array}$ & 789 & 17.9 & 27.8 & 31.1 & 34.2 & 34.2 & 88.6 & 69.9 \\
\hline Cyprus & NA & 29.8 & 101.2 & 87.2 & 101.4 & 78.3 & 92.1 & 106.9 \\
\hline Denmark & 36603 & 23.7 & 51.0 & 45.1 & 53.4 & 53.4 & 84.6 & 64.7 \\
\hline $\begin{array}{r}\text { Dominican } \\
\text { Republic }\end{array}$ & 1707 & 21.6 & 24.2 & 24.3 & 34.5 & 27.1 & 74.7 & 59.1 \\
\hline Ecuador & 1584 & 20.8 & 24 & 22.3 & 26.3 & 24.3 & 63.7 & 48.8 \\
\hline Egypt & 1085 & 22.6 & 66.4 & 25.4 & 81.2 & 78.2 & 60.4 & 50.7 \\
\hline El & 1697 & 16.1 & 30.7 & 27.1 & 36.2 & 36.1 & 70.9 & 56.4 \\
\hline Fiji & 2434 & 20.2 & 39.8 & 23.1 & 27.0 & 27.0 & 96.9 & 101.1 \\
\hline Finland & 26895 & 25.0 & 48.2 & 57.7 & 56.4 & 56.4 & 97.3 & 54.4 \\
\hline France & 27212 & 22.8 & 66.1 & 79.6 & 92.6 & 75.9 & 97.6 & 39.4 \\
\hline Gabon & 4648 & 35.6 & 17.4 & 16.0 & 20.0 & 20.0 & 89.4 & 97.4 \\
\hline Gambia & 348 & 16.2 & 23.4 & 15.9 & 22.5 & 22.5 & 81.0 & 101.9 \\
\hline Ghana & 392 & 12.1 & 18.9 & 5.4 & 25.0 & 2.05 & 34.6 & 36.5 \\
\hline
\end{tabular}


Table A3 (continued): GDP, investment, and financial indicators, average 1965$1997^{\mathrm{a}}$

\begin{tabular}{|c|c|c|c|c|c|c|c|c|}
\hline Country & $\begin{array}{l}G D P \\
\text { per } \\
\text { capita } \\
1997\end{array}$ & $\begin{array}{l}\text { Gross } \\
\text { domestic } \\
\text { investment } \\
(\% \text { GDP })\end{array}$ & $\begin{array}{l}\text { Liquid } \\
\text { liabilities } \\
(\% \\
G D P)\end{array}$ & $\begin{array}{l}\text { Credit } \\
\text { to } \\
\text { private } \\
\text { sector } \\
(\% G D P)\end{array}$ & $\begin{array}{l}\text { Credit } \\
\text { by banks } \\
(\% G D P)\end{array}$ & $\begin{array}{l}\text { Net } \\
\text { Domestic } \\
\text { Credit } \\
(\% \\
G D P)\end{array}$ & $\begin{array}{l}\text { Banks } \\
\text { assets } \\
(\% \\
\text { total })\end{array}$ & $\begin{array}{l}\text { Trade } \\
(\% \\
\text { GDP })\end{array}$ \\
\hline Greece & NA & 26.7 & 54.7 & 35.4 & 74.4 & 53.2 & 74.9 & 36.0 \\
\hline Guatemala & 1496 & 14.7 & 22.9 & 14.8 & 19.5 & 18.5 & 76.7 & 39.8 \\
\hline Guyana & NA & 27 & 64.1 & 22.6 & 135.2 & 129 & 51.9 & 141.5 \\
\hline Haiti & 365 & 12.3 & 25.4 & 11.5 & 28.7 & 28.2 & 26.9 & 37.1 \\
\hline Honduras & 714 & 21.8 & 26.5 & 26.9 & 33.3 & 29.1 & 79.4 & 66.6 \\
\hline Iceland & NA & 23.7 & 32.3 & 36.4 & 40.7 & 40.7 & 91.3 & 70.5 \\
\hline India & 393 & 21.3 & 37.3 & 21.9 & 41.7 & 39.9 & 66.6 & 15.4 \\
\hline Indonesia & 1141 & 23.4 & 23.4 & 23.5 & 25.4 & 25.4 & 77.7 & 43.4 \\
\hline Iran & NA & 25.3 & 52.1 & 31.4 & 55.9 & 51.6 & 53.1 & 38.5 \\
\hline Ireland & 21063 & 22 & 55.0 & 43.5 & 54.4 & 40.4 & 95.7 & 101.5 \\
\hline Israel & 15868 & 24.4 & 69.5 & 52.5 & 96.8 & 96.8 & 86.3 & 87.0 \\
\hline Italy & 19325 & 23 & 77.6 & 59.7 & 93.0 & 93.1 & 87.6 & 40.4 \\
\hline Jamaica & 1570 & 26.4 & 43.9 & 28.8 & 42.9 & 38.0 & 75.7 & 95.0 \\
\hline Japan & 42701 & 32.1 & 145.9 & 148.4 & 199.4 & 112.3 & 96.5 & 21.6 \\
\hline Jordan & 1523 & 31.5 & 83.1 & 49.2 & 65.9 & 60.3 & 83.3 & 123.3 \\
\hline Kenya & 336 & 22.2 & 37.3 & 25.6 & 38.4 & 29.5 & 81.2 & 60.3 \\
\hline Korea & 11209 & 30.1 & 43.6 & 49.6 & 52.6 & 45.6 & 90.0 & 59.1 \\
\hline Lesotho & 515 & 41.7 & 37.4 & 15.0 & 18.4 & 19.6 & 75.9 & 124.3 \\
\hline Madagascar & 236 & 10.4 & 20.3 & 16.4 & 25.4 & 25.4 & 63.9 & 38.9 \\
\hline Malawi & 166 & 20.7 & 22.5 & 12.7 & 24.4 & 22.1 & 68.3 & 60.1 \\
\hline Malaysia & 4720 & 29.3 & 76.7 & 61 & 76.9 & 52.2 & 96.1 & 113.9 \\
\hline Mali & 266 & 18.9 & 19.5 & 16.8 & 29.5 & 29.5 & 54.7 & 46 \\
\hline Malta & 9227 & 27.9 & 147.6 & 54.5 & 61.2 & 51.7 & 96.0 & 165.6 \\
\hline Mauritania & 475 & 25 & 19.1 & 25.5 & 28.3 & 28.3 & 81.3 & 101.5 \\
\hline Mauritius & 3827 & 23.5 & 50.3 & 27.1 & 43.9 & 43.9 & 84.2 & 106.2 \\
\hline Mexico & 3412 & 21.7 & 26.8 & 19.8 & 40.2 & 25.1 & 67.3 & 27.5 \\
\hline Morocco & 1327 & 21.8 & 48.5 & 26.5 & 52.5 & 41.6 & 90.1 & 50.0 \\
\hline Nepal & 216 & 15.6 & 23.3 & 9.1 & 18.3 & 18.3 & 61.7 & 30.0 \\
\hline Netherlands & 27196 & 22.5 & 75.4 & 74.3 & 103.1 & 79.4 & 98.9 & 96.4 \\
\hline $\begin{array}{l}\text { New } \\
\text { Zealand }\end{array}$ & 16835 & 23.7 & 52.6 & 33.7 & 38.5 & 38.4 & 86.1 & 54.9 \\
\hline Nicaragua & NA & 20.5 & 31.3 & 30.4 & 76.5 & 75.9 & 65.7 & 63.4 \\
\hline Niger & 205 & 11.1 & 12.5 & 10.7 & 11.8 & 11.8 & 80.1 & 41.5 \\
\hline Nigeria & 264 & 18.4 & 20.9 & 10 & 22.3 & 22.3 & 61.3 & 46.9 \\
\hline Norway & 36319 & 28.5 & 53.5 & 59.5 & 73.9 & 54.9 & 91.7 & 74.4 \\
\hline Pakistan & 497 & 16.7 & 43.3 & 26.2 & 49.2 & 49.2 & 69.9 & 31.0 \\
\hline Panama & NA & 20.7 & 38.4 & 54.2 & 59.6 & 58.1 & 75.1 & 163.4 \\
\hline $\begin{array}{l}\text { Papua New } \\
\text { Guinea }\end{array}$ & 1089 & 24.8 & 32.1 & 21.1 & 24.7 & 24.7 & 88.2 & 86.6 \\
\hline Paraguay & 1851 & 21.8 & 21.4 & 18.3 & 21.1 & 17.1 & 67.9 & 41 \\
\hline Peru & 2663 & 23.4 & 20.7 & 13.9 & 21.2 & 18.1 & 87.4 & 32.4 \\
\hline Philippines & 1123 & 23.7 & 32.9 & 31.8 & 42.7 & 35.8 & 83.0 & 52.7 \\
\hline
\end{tabular}


Table A3 (end): GDP, investment, and financial indicators, average $1965-1997^{\mathrm{a}}$

\begin{tabular}{|c|c|c|c|c|c|c|c|c|}
\hline Country & $\begin{array}{l}\text { GDP } \\
\text { per } \\
\text { capita } \\
1997\end{array}$ & $\begin{array}{l}\text { Gross } \\
\text { domestic } \\
\text { investment } \\
(\% \text { GDP })\end{array}$ & $\begin{array}{l}\text { Liquid } \\
\text { liabilities } \\
(\% \\
\text { GDP })\end{array}$ & $\begin{array}{l}\text { Credit } \\
\text { to } \\
\text { private } \\
\text { sector } \\
(\% G D P)\end{array}$ & $\begin{array}{l}\text { Credit } \\
\text { by banks } \\
(\% G D P)\end{array}$ & $\begin{array}{l}\text { Net } \\
\text { Domestic } \\
\text { Credit } \\
(\% \text { GDP })\end{array}$ & $\begin{array}{l}\text { Banks } \\
\text { assets } \\
(\% \\
\text { total })\end{array}$ & $\begin{array}{l}\text { Trade } \\
(\% \\
G D P)\end{array}$ \\
\hline Portugal & 11295 & 27.2 & 89.3 & 63.8 & 84.0 & 84.0 & NA & 60.6 \\
\hline Rwanda & 209 & 12.2 & 14.4 & 5.3 & 11.1 & 11.1 & 57.2 & 30.8 \\
\hline Senegal & 569 & 13.1 & 22.6 & 26.3 & 31.4 & 31.4 & 84.4 & 64.6 \\
\hline Seychelles & 7145 & 30.0 & 39.4 & 13.7 & 35.5 & 35.5 & 84.6 & 131.8 \\
\hline Singapore & 31600 & 37.3 & 90.8 & 78.9 & 55.8 & 46.5 & NA & 329.6 \\
\hline $\begin{array}{l}\text { South } \\
\text { Africa }\end{array}$ & 3454 & 23.7 & 53.7 & 77.4 & 98.4 & 61.3 & 94.9 & 51.9 \\
\hline Spain & 15089 & 24 & 76.7 & 72.1 & 95.2 & 90.2 & 71.8 & 34.6 \\
\hline Sri Lanka & 775 & 22.6 & 34.0 & 17.6 & 35.2 & 35.2 & 60.2 & 67.4 \\
\hline Sudan & 292 & 14.4 & 21.7 & 8.9 & 25.8 & 25.8 & 54.8 & 28.9 \\
\hline Swaziland & 1425 & 26.3 & 30.9 & 21.1 & 10.9 & 10.9 & 96.2 & 149.7 \\
\hline Sweden & 26786 & 20.3 & 53.1 & 82.2 & 102.8 & 69.4 & 89.3 & 57.8 \\
\hline Switzerland & 44108 & 26.6 & 127.2 & 126.2 & 139.2 & 139.2 & 99 & 65.5 \\
\hline Syria & 1181 & 21.3 & 47.1 & 8.3 & 57.6 & 57.0 & 45.6 & 49.8 \\
\hline Thailand & 2915 & 30.1 & 51.4 & 55.8 & 66.0 & 52.7 & 87.1 & 54.6 \\
\hline Togo & 344 & 20.5 & 29.4 & 19.6 & 19.6 & 19.6 & 82.3 & 86.6 \\
\hline $\begin{array}{l}\text { Trinidad } \\
\text { and } \\
\text { Tobago }\end{array}$ & 4337 & 22.5 & 42.2 & 34.4 & 32.4 & 24.2 & 91.3 & 82.8 \\
\hline Tunisia & 2203 & 26.8 & 44.5 & 50.3 & 57.7 & 51.2 & 94 & 69.6 \\
\hline Turkey & 3054 & 19.2 & 25.1 & 18.1 & 33.4 & 31.2 & 70.7 & 25.4 \\
\hline $\begin{array}{l}\text { United } \\
\text { Kingdom }\end{array}$ & 19867 & 18.4 & NA & 57.8 & 72.2 & 72.2 & 86.8 & 51.0 \\
\hline $\begin{array}{l}\text { United } \\
\text { States }\end{array}$ & 29094 & 19.0 & 65.9 & 84.9 & 105.1 & 81.7 & 89.6 & 17.3 \\
\hline Uruguay & 6110 & 16.6 & 39.1 & 31.1 & 45.0 & 45.0 & 60.0 & 37.7 \\
\hline Venezuela & 3549 & 25.0 & 37.9 & 32.2 & 34.2 & 22.1 & 89.7 & 47.1 \\
\hline Zambia & 408 & 21.8 & 28.2 & 15.9 & 44.8 & 42.8 & 54.5 & 78.9 \\
\hline Zimbabwe & 689 & 18.5 & 35.8 & 22.9 & 39.8 & 27.6 & 60.6 & 51.2 \\
\hline
\end{tabular}

Note: NA = not available.

Sources: Author's computations using data from: World Bank, World Development Indicators 1999; IMF, International Financial Statistics, December 1999. 
Table A4: Full results for Table 6: Effects of financial structure vs. financial development

\begin{tabular}{|c|c|c|c|c|}
\hline \multirow[t]{2}{*}{ Explanatory variables } & \multicolumn{2}{|c|}{ No fixed effects $(O L S)$} & \multicolumn{2}{|c|}{ With fixed effects $(L S D V)$} \\
\hline & $\begin{array}{l}\text { Without } \\
\text { liquid } \\
\text { liabilities }\end{array}$ & $\begin{array}{l}\text { With liquid } \\
\text { liabilities }\end{array}$ & $\begin{array}{c}\text { Without } \\
\text { liquid } \\
\text { liabilities }\end{array}$ & $\begin{array}{l}\text { With liquid } \\
\text { liabilities }\end{array}$ \\
\hline FD_DUMMY*growth & $\begin{array}{l}0.0057 \\
(0.002)\end{array}$ & $\begin{array}{l}0.0036 \\
(0.058)\end{array}$ & $\begin{array}{r}0.0073 \\
(0.003)\end{array}$ & $\begin{array}{l}0.0089 \\
(0.003)\end{array}$ \\
\hline Liquid liabilities & & $\begin{array}{r}0.032 \\
(0.0001)\end{array}$ & & $\begin{array}{r}0.344 \\
(0.001)\end{array}$ \\
\hline Lagged investment & $\begin{array}{r}0.828 \\
(0.0001)\end{array}$ & $\begin{array}{r}0.811 \\
(0.0001)\end{array}$ & $\begin{array}{r}0.667 \\
(0.0001)\end{array}$ & $\begin{array}{r}0.543 \\
(0.0001)\end{array}$ \\
\hline Output growth & $\begin{array}{r}0.0038 \\
(0.0001)\end{array}$ & $\begin{array}{r}0.0041 \\
(0.0001)\end{array}$ & $\begin{array}{r}0.0032 \\
(0.0004)\end{array}$ & $\begin{array}{r}0.0064 \\
(0.0001)\end{array}$ \\
\hline Trade & $\begin{array}{r}0.0297 \\
(0.0001)\end{array}$ & $\begin{array}{r}0.0237 \\
(0.0007)\end{array}$ & $\begin{array}{r}0.365 \\
(0.0001)\end{array}$ & $\begin{array}{r}0.451 \\
(0.0001)\end{array}$ \\
\hline Intercept & $\begin{array}{r}0.395 \\
(0.0001)\end{array}$ & $\begin{array}{r}0.357 \\
(0.0001)\end{array}$ & & \\
\hline $\begin{array}{l}\text { Adj. R2 } \\
\text { Observations }\end{array}$ & $\begin{array}{r}0.76 \\
2925 \\
\end{array}$ & $\begin{array}{r}0.77 \\
2860 \\
\end{array}$ & $\begin{array}{r}0.45 \\
2918 \\
\end{array}$ & $\begin{array}{r}0.36 \\
2845 \\
\end{array}$ \\
\hline
\end{tabular}

Note: FD_DUMMY $=1$ if the country is "financially developed" and 0 otherwise.

Panel b (corresponding to row [2] in Table 6): stock-market based dummy*growth

\begin{tabular}{lrrrr}
\hline Explanatory variables & \multicolumn{2}{c}{ No fixed effects $(O L S)$} & \multicolumn{2}{l}{ With fixed effects $(L S D V)$} \\
\hline & $\begin{array}{c}\text { Without } \\
\text { liquid } \\
\text { liabilities }\end{array}$ & $\begin{array}{l}\text { With liquid } \\
\text { liabilities }\end{array}$ & $\begin{array}{l}\text { Without } \\
\text { liquid } \\
\text { liabilities }\end{array}$ & $\begin{array}{c}\text { With liquid } \\
\text { liabilities }\end{array}$ \\
SMB_DUMMY*growth & 0.0033 & 0.0032 & 0.0038 & 0.0018 \\
& $(0.017)$ & $(0.023)$ & $(0.041)$ & $(0.442)$ \\
Liquid liabilities & & 0.0103 & & 0.268 \\
& & $(0.12)$ & & $(0.04)$ \\
Lagged investment & 0.0818 & 0.810 & 0.668 & 0.525 \\
& $(0.0001)$ & $(0.0001)$ & $(0.0001)$ & $(0.0001)$ \\
Output growth & 0.0059 & 0.006 & 0.0072 & 0.012 \\
& $(0.0001)$ & $(0.0001)$ & $(0.0001)$ & $(0.0001)$ \\
Trade & 0.0161 & 0.0126 & 0.265 & 0.286 \\
& $(0.001)$ & $(0.017)$ & $(0.0005)$ & $(0.0005)$ \\
Intercept & 0.4889 & 0.490 & & \\
& $(0.0001)$ & $(0.0001)$ & & \\
Adj. R2 & 0.79 & 0.79 & 0.59 & 0.50 \\
Observations & 1604 & 1562 & 1602 & 1557 \\
\hline
\end{tabular}

Note: SMB_DUMMY = 1 if the country has a stock-market based system and 0 if it has a bank-based system. 
Panel c (corresponding to row [3] in Table 6): developed stock-market based dummy*growth

\begin{tabular}{|c|c|c|c|c|}
\hline Explanatory variables & No fixed ef & $\operatorname{cts}(O L S)$ & With fixed ef. & ets $(L S D V)$ \\
\hline & $\begin{array}{l}\text { Without } \\
\text { liquid } \\
\text { liabilities }\end{array}$ & $\begin{array}{l}\text { With liquid } \\
\text { liabilities }\end{array}$ & $\begin{array}{l}\text { Without } \\
\text { liquid } \\
\text { liabilities }\end{array}$ & $\begin{array}{l}\text { With liquid } \\
\text { liabilities }\end{array}$ \\
\hline DEVMB_DUMMY*growth & $\begin{array}{l}0.0038 \\
(0.022)\end{array}$ & $\begin{array}{l}0.0047 \\
(0.006)\end{array}$ & $\begin{array}{l}0.0013 \\
(0.303)\end{array}$ & $\begin{array}{l}0.0012 \\
(0.333)\end{array}$ \\
\hline Liquid liabilities & & $\begin{array}{r}0.027 \\
(0.009)\end{array}$ & & $\begin{array}{l}0.035 \\
(0.06)\end{array}$ \\
\hline Lagged investment & $\begin{array}{r}0.859 \\
(0.0001)\end{array}$ & $\begin{array}{r}0.836 \\
(0.0001)\end{array}$ & $\begin{array}{r}0.717 \\
(0.0001)\end{array}$ & $\begin{array}{r}0.7222 \\
(0.0001)\end{array}$ \\
\hline Output growth & $\begin{array}{r}0.0067 \\
(0.0001)\end{array}$ & $\begin{array}{r}0.0069 \\
(0.0001)\end{array}$ & $\begin{array}{r}0.0085 \\
(0.0001)\end{array}$ & $\begin{array}{r}0.0082 \\
(0.0001)\end{array}$ \\
\hline Trade & $\begin{array}{r}0.0104 \\
(0.09)\end{array}$ & $\begin{array}{r}0.0099 \\
(0.11)\end{array}$ & $\begin{array}{l}0.128 \\
(0.39)\end{array}$ & $\begin{array}{r}0.0039 \\
(0.87)\end{array}$ \\
\hline Intercept & $\begin{array}{r}0.381 \\
(0.0001)\end{array}$ & $\begin{array}{r}0.344 \\
(0.0001)\end{array}$ & & \\
\hline $\begin{array}{l}\text { Adj. R2 } \\
\text { Observations }\end{array}$ & $\begin{array}{r}0.83 \\
780\end{array}$ & $\begin{array}{r}0.82 \\
746\end{array}$ & $\begin{array}{r}0.59 \\
780\end{array}$ & $\begin{array}{r}0.59 \\
744\end{array}$ \\
\hline
\end{tabular}

Note: DEVMB_DUMMY $=1$ if the country has a developed stock-market based system and 0 otherwise.

Panel d (corresponding to row [4] in Table 6): underdeveloped stock-market based dummy*growth

\begin{tabular}{|c|c|c|c|c|}
\hline Explanatory variables & \multicolumn{2}{|c|}{ No fixed effects $(O L S)$} & \multicolumn{2}{|c|}{ With fixed effects (LSDV) } \\
\hline & $\begin{array}{l}\text { Without } \\
\text { liquid } \\
\text { liabilities }\end{array}$ & $\begin{array}{c}\text { With liquid } \\
\text { liabilities }\end{array}$ & $\begin{array}{c}\text { Without } \\
\text { liquid } \\
\text { liabilities }\end{array}$ & $\begin{array}{c}\text { With liquid } \\
\text { liabilities }\end{array}$ \\
\hline UNDEVMB_DUMMY*growth & $\begin{array}{l}0.0024 \\
(0.306)\end{array}$ & $\begin{array}{l}0.0011 \\
(0.631)\end{array}$ & $\begin{array}{l}0.0027 \\
(0.292)\end{array}$ & $\begin{array}{l}0.0013 \\
(0.596)\end{array}$ \\
\hline Liquid liabilities & & $\begin{array}{r}0.0435 \\
(0.22)\end{array}$ & & $\begin{array}{r}0.0277 \\
(0.13)\end{array}$ \\
\hline Lagged investment & $\begin{array}{r}0.786 \\
(0.0001)\end{array}$ & $\begin{array}{r}0.797 \\
(0.0001)\end{array}$ & $\begin{array}{r}0.796 \\
(0.0001)\end{array}$ & $\begin{array}{r}0.776 \\
(0.0001)\end{array}$ \\
\hline Output growth & $\begin{array}{r}0.0052 \\
(0.0004)\end{array}$ & $\begin{array}{r}0.0064 \\
(0.0001)\end{array}$ & $\begin{array}{r}0.0055 \\
(0.0005)\end{array}$ & $\begin{array}{r}0.0071 \\
(0.0001)\end{array}$ \\
\hline Trade & $\begin{array}{c}0.0198 \\
(0.013)\end{array}$ & $\begin{array}{l}0.1175 \\
(0.004)\end{array}$ & $\begin{array}{r}0.136 \\
(0.0009)\end{array}$ & $\begin{array}{r}0.114 \\
(0.004)\end{array}$ \\
\hline Intercept & $\begin{array}{r}0.574 \\
(0.0001)\end{array}$ & $\begin{array}{r}0.612 \\
(0.0001)\end{array}$ & & \\
\hline Adj. R2 & 0.73 & $\begin{array}{r}0.73 \\
813\end{array}$ & $\begin{array}{r}0.62 \\
823\end{array}$ & 0.64 \\
\hline
\end{tabular}

Note: UNDEVMB_DUMMY $=1$ if the country has an underdeveloped stock-market based system and 0 otherwise. 
Panel e (corresponding to rows [5]-[7] in Table 6): Financial structure dummies*growth (entered simultaneously)

\begin{tabular}{|c|c|c|c|c|}
\hline \multirow[t]{4}{*}{ Explanatory variables } & \multicolumn{2}{|c|}{ No fixed effects $(O L S)$} & \multicolumn{2}{|c|}{ With fixed effects (LSDV) } \\
\hline & Without & With liquid & Without & With liquid \\
\hline & liquid & liabilities & liquid & liabilities \\
\hline & liabilities & & liabilities & \\
\hline \multirow[t]{2}{*}{ DEVBB_DUMMY*growth } & 0.0024 & 0.0017 & 0.0029 & 0.0036 \\
\hline & $(0.165)$ & $(0.315)$ & $(0.196)$ & $(0.229)$ \\
\hline \multirow[t]{2}{*}{ DEVMB_DUMMY*growth } & 0.0064 & 0.0062 & 0.0077 & 0.0064 \\
\hline & $(0.001)$ & $(0.002)$ & $(0.01)$ & $(0.101)$ \\
\hline \multirow[t]{2}{*}{ UNDEVMB_DUMMY*growth } & 0.0021 & 0.0013 & 0.0038 & 0.0020 \\
\hline & $(0.29)$ & $(0.511)$ & $(0.108)$ & $(0.480)$ \\
\hline \multirow[t]{2}{*}{ Liquid liabilities } & & 0.054 & & 0.276 \\
\hline & & $(0.04)$ & & $(0.04)$ \\
\hline \multirow[t]{2}{*}{ Lagged investment } & 0.814 & 0.809 & 0.674 & 0.528 \\
\hline & $(0.0001)$ & $(0.0001)$ & $(0.0001)$ & $(0.0001)$ \\
\hline \multirow[t]{2}{*}{ Output growth } & 0.0051 & 0.0058 & 0.0058 & 0.010 \\
\hline & $(0.0001)$ & $(0.0001)$ & $(0.0001)$ & $(0.0001)$ \\
\hline \multirow[t]{2}{*}{ Trade } & 0.0014 & 0.013 & 0.252 & 0.273 \\
\hline & $(0.004)$ & $(0.001)$ & $(0.0006)$ & (0.006) \\
\hline \multirow[t]{2}{*}{ Intercept } & 0.509 & 0.828 & & \\
\hline & $(0.0001)$ & $(0.0001)$ & & \\
\hline Adj. R2 & 0.79 & & 0.59 & 0.50 \\
\hline Observations & 1604 & & 1602 & 1557 \\
\hline
\end{tabular}

Note: DEVBB_DUMMY $=1$ if the country has a developed bank-market based system and 0 otherwise; other dummies are defined as in panels (a)-(d).

In all the panels (a)-(e), the dependent variable is the logarithm of gross domestic investment as percentage of GDP. The p-values are given in parenthesis. 